OAK RIDGE

NATIONAL

LABORATIRY

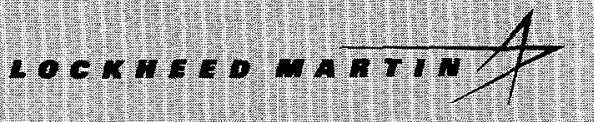

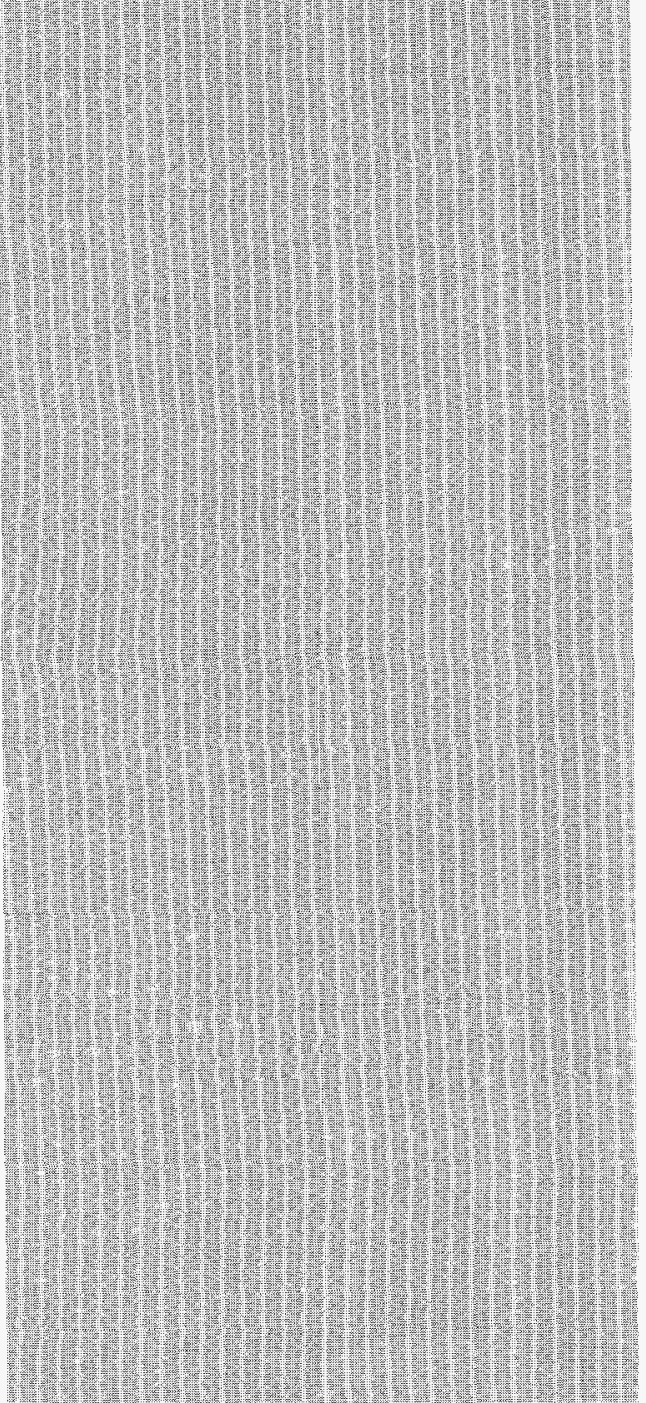

MANAGED ANO OPERATED BY LOCKHEED WARTIN EIERGY RESEARCH CORPORATION FORTHEUUEDS STATES

DEPARTUENT OF ENERGY

\section{Grout Performance in Support of In Situ Grouting of the TH4 Tank Sludge}

\author{
R. D. Spence \\ R. D. Hunt \\ J. L. Kauschinger
}


This report has been reproduced directly from the best available copy.

Available to DOE and DOE contractors from the Office of Scientific and Technical Information, P.O. Box 62, Oak Ridge, TN 37831; prices available from (615) 576-8401, FTS 626-8401.

Available to the public from the National Technical Information Service, U.S. Department of Commerce, 5285 Port Royal Rd., Springfield, VA 22161.

This report was prepared as an account of work sponsored by an agency of the United States Government. Neither the United States Government nor any agency thereof, nor any of their employees, makes any warranty, express or implied, or assumes any legal liability or responsibility for the accuracy, completeness, or usefulness of any information, apparatus, product, or process disclosed, or represents that its use would not infringe privately owned rights. Reference herein to any specific commercial product, process, or service by trade name, trademark, manufacturer, or otherwise, does not necessarily constitute or imply its endorsement, recommendation, or favoring by the United States Government or any agency thereof. The views and opinions of authors expressed herein do not necessarily state or reflect those of the United States Government or any agency thereof. 


\section{DISCLAIMER}

Portions of this document may be illegible in electronic image products. Images are produced from the best available original document. 
Chemical Technology Division

\title{
Grout Performance in Support of In Situ Grouting of the TH4 Tank Sludge
}

\author{
R. D. Spence \\ R. D. Hunt \\ J. L. Kauschinger*
}

${ }^{*}$ Ground Environmental Services, Inc., 200 Berry Glen Court, Alpharetta, Georgia 30202.

Date Published: April 1999

\author{
Prepared by \\ OAK RIDGE NATIONAL LABORATORY \\ Oak Ridge, Tennessee 37831-6285 \\ managed by \\ LOCKHEED MARTIN ENERGY RESEARCH CORP. \\ for the \\ U.S. DEPARTMENT OF ENERGY \\ under contract DE-AC05-96OR22464
}





\section{CONTENTS}

LIST OF TABLES $\ldots \ldots \ldots \ldots \ldots \ldots \ldots \ldots \ldots \ldots \ldots \ldots \ldots \ldots \ldots \ldots \ldots \ldots \ldots$

LIST OF FIGURES $\ldots \ldots \ldots \ldots \ldots \ldots \ldots \ldots \ldots \ldots \ldots \ldots \ldots \ldots \ldots \ldots \ldots \ldots \ldots$ vii

EXECUTIVE SUMMARY $\ldots \ldots \ldots \ldots \ldots \ldots \ldots \ldots \ldots \ldots \ldots \ldots \ldots \ldots \ldots \ldots$ ix

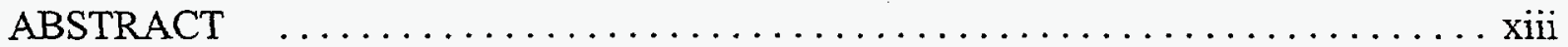

1. INTRODUCTION $\ldots \ldots \ldots \ldots \ldots \ldots \ldots \ldots \ldots \ldots \ldots \ldots \ldots \ldots \ldots \ldots \ldots \ldots \ldots$

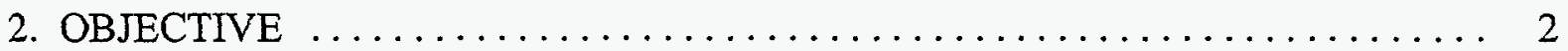

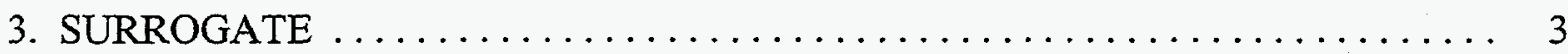

4. SELECTION OF THE DRY-BLEND ADDITIVES $\ldots \ldots \ldots \ldots \ldots \ldots \ldots \ldots$

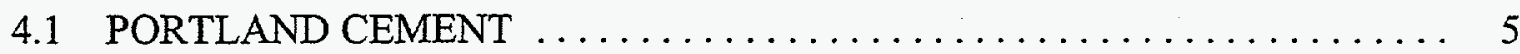

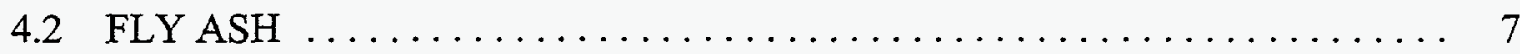

4.3 INDIAN RED POTTERY CLAY $\ldots \ldots \ldots \ldots \ldots \ldots \ldots \ldots \ldots \ldots \ldots$

4.4 GROUND GRANULATED BLAST FURNACE SLAG $\ldots \ldots \ldots \ldots \ldots \ldots$

4.5 WATER-SORPTIVE SUSPENSION AGENTS $\ldots \ldots \ldots \ldots \ldots \ldots \ldots \ldots$

5. EXPERIMENTAL ................................... 13

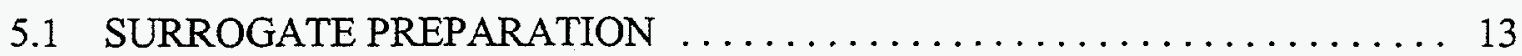

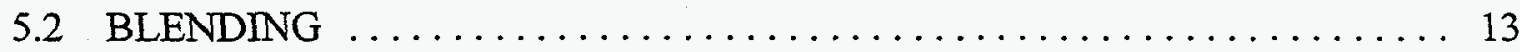

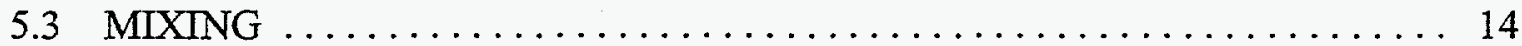

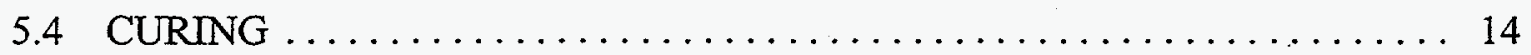

5.5 PERFORMANCE TESTING $\ldots \ldots \ldots \ldots \ldots \ldots \ldots \ldots \ldots \ldots \ldots \ldots \ldots \ldots \ldots \ldots \ldots \ldots$

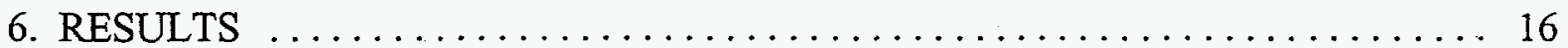

6.1 SCOPING TESTS AND FINAL SELECTION $\ldots \ldots \ldots \ldots \ldots \ldots \ldots \ldots$

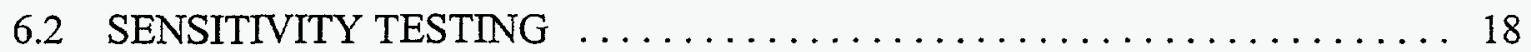

6.3 HOT TESTING WITH A SAMPLE OF THE TH4 SLUDGE $\ldots \ldots \ldots \ldots .21$

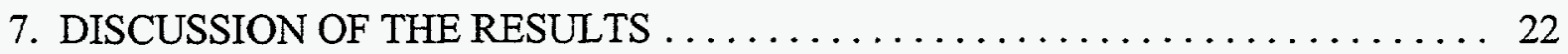

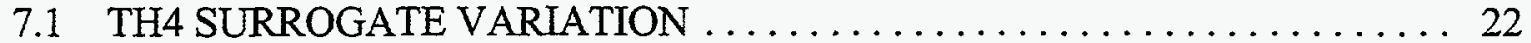

7.2 DRY SLUDGE AND LEVELS OF TREATMENT IN THE TH $4 \ldots \ldots \ldots \ldots$

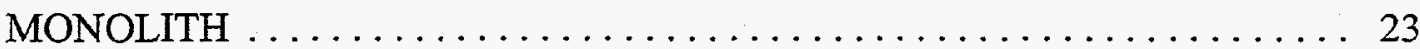

7.3 PERCENTAGE OF POSSOLAN IN MONOLITH $\ldots \ldots \ldots \ldots \ldots \ldots \ldots 25$

7.4 MECHANICAL STRENGTH AND LEACH RESISTANCE OF TREATED

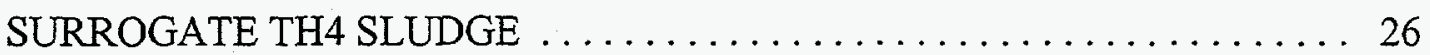

7.5 HOT TESTING OF ACTUAL TH-4 SLUDGE SAMPLES $\ldots \ldots \ldots \ldots \ldots 30$

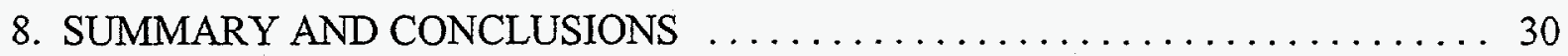

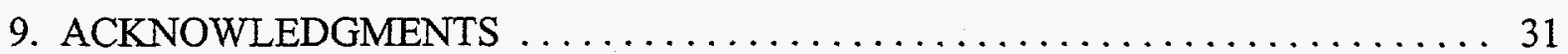


CONTENTS (continued)

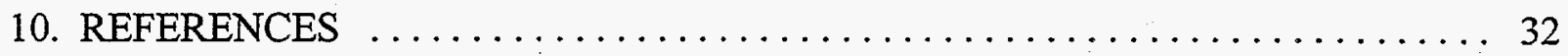

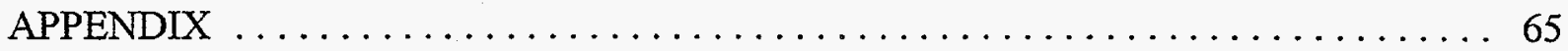




\section{LIST OF TABLES}

1 Composition of TH4 sludge sample and GAAT surrogates $\ldots \ldots \ldots \ldots \ldots . . \ldots 39$

2 Composition of the surrogate $\mathrm{TH} 2$ sludge $\ldots \ldots \ldots \ldots \ldots \ldots \ldots \ldots \ldots, 40$

3 Jetting slurry compositions for tests finalizing the jetting slurry .......... 41

$4 \quad$ Jetting slurry density for the tests finalizing the jetting slurry $\ldots \ldots \ldots \ldots \ldots .42$

5 Jetting slurry unconfined compressive strength for the tests finalizing the jetting

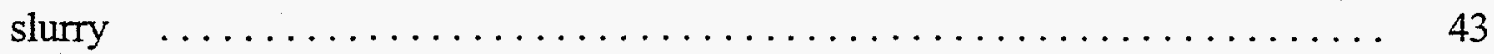

6 Grout composition for screening tests with surrogate $\mathrm{TH} 4$ sludge $\ldots \ldots \ldots \ldots 43$

7 Grout density and grout:sludge volume ratio for screening tests with surrogate TH4 sludge ................................... 44

8 Bleed water for screening tests with surrogate TH4 sludge $\ldots \ldots \ldots \ldots \ldots \ldots 44$

9 Penetration resistance for screening tests with surrogate TH4 sludge ........ 44

10 Unconfined compressive strength for screening tests with surrogate TH4 sludge . 44

11 TCLP extract concentrations for screening tests with surrogate TH4 sludge .... 44

12 Composition of grouts for $\mathrm{TH} 4$ sensitivity testing $\ldots \ldots \ldots \ldots \ldots \ldots \ldots \ldots$

13 Density and volume ratio for TH4 sensitivity testing $\ldots \ldots \ldots \ldots \ldots \ldots . \ldots 46$

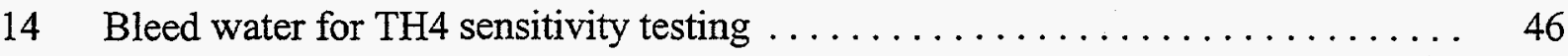

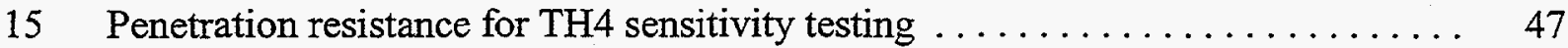

16 Unconfined compressive strength for TH4 sensitivity testing . . . . . . . . . 47

17 TCLP extract concentrations for $\mathrm{TH} 4$ sensitivity testing $\ldots \ldots \ldots \ldots \ldots \ldots .48$

$18 \quad{ }^{85} \mathrm{Sr}$ and ${ }^{137} \mathrm{Cs}$ leachability indices for $\mathrm{TH} 4$ sensitivity testing . . . . . . . . . . 48

19 Total concentrations measured in the slag samples $(\mathrm{mg} / \mathrm{kg}) \ldots \ldots \ldots \ldots \ldots . \ldots 49$

20 Chemical analysis of sludge sample from GAAT TH $4 \ldots \ldots \ldots \ldots \ldots .50$

21 Density, penetration resistance, compressive strength, and leachability indices

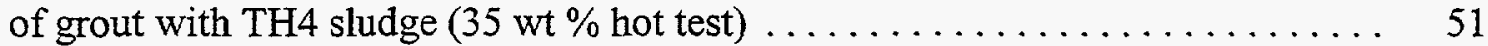

22 TCLP results on the GAAT TH-4 sludge and the grout sample with TH4 sludge . 52 



\section{LIST OF FIGURES}

Figure

Page

1 Photographs of the TH4 sludge sample $\ldots \ldots \ldots \ldots \ldots \ldots \ldots \ldots \ldots \ldots$

2 Water content vs percent waste loading of wet sludge used in surrogate TH4 tests

3 Comparison between percentage of dry surrogate $\mathrm{TH} 4$ sludge vs water:possolan

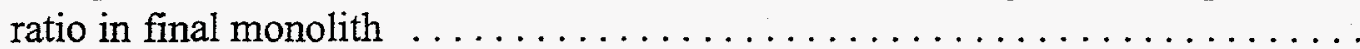

4 Comparison between percentage of possolan and water:pozzolan ratio for the

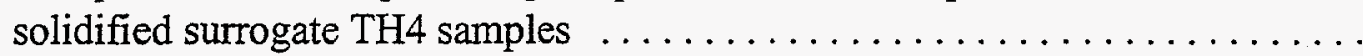

5 Comparison between unconfined compressive strength vs water/pozzolan ratio in solidified surrogate $\mathrm{TH} 4$

6 Comparison between RCRA metal TCLP extract concentration vs unconfined compressive strength, surrogate $\mathrm{TH} 4$ sludge $\ldots \ldots \ldots \ldots \ldots \ldots \ldots$

7 Comparison between chromium TCLP extract concentration vs percentage of pozzolan in final mixture, surrogate $\mathrm{TH} 4$ sludge $\ldots \ldots \ldots \ldots \ldots \ldots \ldots$

8 Comparison between lead TCLP extract concentration vs percentage of pozzolan in final mixture, surrogate $\mathrm{TH} 4$ sludge $\ldots \ldots \ldots \ldots \ldots \ldots \ldots \ldots \ldots \ldots \ldots \ldots$

9 Comparison between mercury TCLP extract concentration vs percentage of pozzolan in final mixture, surrogate $\mathrm{TH} 4$ sludge $\ldots \ldots \ldots \ldots \ldots \ldots$

10 Leachability index measured for ${ }^{85}$ strontium vs percentage of possolan in

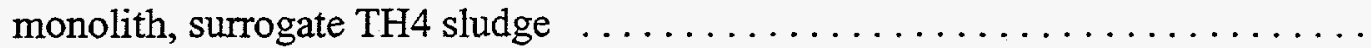

11 Leachability index measured for ${ }^{137}$ cesium versus percentage of pozzolan in monolith, surrogate $\mathrm{TH} 4$ sludge 


\section{EXECUTIVE SUMMARY}

The Gunite and Associated Tanks (GAAT) were constructed at Oak Ridge National Laboratory (ORNL) between 1943 and 1951 and were used for many years to collect radioactive and chemical wastes generated by ORNL operations. These tanks are currently inactive and have not been used to collect these waste solutions and sludges for many years. Much of the sludge accumulated in these tanks was removed and disposed via the Hydrofracture Program. In addition, a project is currently under way to move the remainder of this sludge and supernatant to the Melton Valley Storage Tanks (MVST) for solidification and disposal with other ORNL tank sludges. The robotic apparatus being used for this removal did not fit into the smaller TH4 tank, so in situ grouting was proposed to demonstrate closure of this tank. The GAAT sludges contain a high amount of radioactivity (mainly ${ }^{90} \mathrm{Sr}$ and ${ }^{137} \mathrm{Cs}$ ). Some Resource Conservation and Recovery Act of 1976 (RCRA) metal concentrations are high enough in the available total constituent analysis for the GAAT sludges to be potentially RCRA hazardous (the GAAT sludges have been found characteristically hazardous for mercury via TCLP); therefore, these sludges are presumed to be mixed waste.

Grouting and vitrification are currently the most likely stabilization/solidification alternatives for mixed wastes. Grouting has been used to stabilize/solidify hazardous and low-level radioactive waste for decades. Vitrification has been developed as a high-level radioactive alternative for decades and has been under development recently as a mixed-waste alternative disposal technology. In situ grouting of tank sludges via Multi-Point Injection'1 (MPI, a patented, proprietary technique) is being investigated as a low-cost alternative to: (1) mobilization of these sludges to the Melton Valley Storage Tanks for later solidification and disposal; (2) ex situ grouting of these sludges, followed by either disposal back in the tanks or containerizing and disposal elsewhere; and (3) vitrification of the sludges. The usual disadvantage of volume increase by grouting does not apply in this case if the grout is disposed in place in the existing tanks. (The current plan is to fill the tanks for structural stability and leave them in place whether the sludge is removed or stabilized in place.) This technology is a potential candidate for treating 
the large quantities of sludges present on the other U.S. Department of Energy sites (e.g., Hanford, Savannah River, and Idaho).

The current development effort builds on the previous work of developing a grout formulation for in situ grouting of the GAAT tanks ${ }^{2}$. The dry blend developed in this effort was field tested in a cold demonstration at Duncan, Oklahoma. This field test established the composition of the jetting slurry that was still pumpable by the full-scale Halliburton pumps: 1.9, 30.9, and $67.2 \mathrm{wt}$ $\%$ bentonite, water, and field blend $(10.3,41.0,41.0,7.2$, and 0.5 wt $\%$ of cement, slag, fly ash, illite clay, and fluidizing admixture, respectively). The water content required for pumpability proved to be significantly less in this field test than had been surmised during the prior laboratory development. This field test established the target jetting slurry for further laboratory testing. This report documents the laboratory surrogate and hot testing of the field-adjusted jetting slurry for in situ grouting of the TH4 sludge. The results targeted a $35 \mathrm{wt} \%$ loading of the TH4 sludge, calculated for in situ grouting of the sludge inventory during this work.

The sample formulation used during the cold field demonstration exhibited sufficient waste immobilization and physical strength characteristics throughout all phases of the 1998 benchscale tests. The small amount of CFR-3 dispersant had no impact on the strength, leach and diffusion resistance of the samples tested.

Large amounts ( 38 tons) of dry-blend material can be mixed at a bulk-blending facility and produce a dry blend with qualities similar to those measured on laboratory-scale samples (i.e., can uniformly blend large bulk samples for use during production remediation of Tank TH4).

In situ grouting of the TH4 sludge by MPI can produce grouts resistant to solids segregation with no free water that stabilize the RCRA metals within Toxicity Characteristic Leaching Procedure (TCLP) limits and provide excellent leach resistance for the radionuclides. This conclusion is backed by testing with a challenging surrogate of TH4 sludge and confirmed by testing with an actual sample of TH4 sludge. This tank sludge can be stabilized at a wet sludge loading of 
$35 \mathrm{wt} \%$ (or higher), resulting in a volume increase of about $132 \mathrm{vol} \%$, with little or no secondary waste generation. The grout strength develops slowly, but is expected to exceed 1000 psi. The strength is sensitive to waste loading and pozzolanic content, but even the worst grouts tested were firm and strong enough to support anticipated overburdens. In situ grouting stabilizes the RCRA metals to meet TCLP criteria, including mercury, potentially a problem species for the tank sludges. The grout selected for sensitivity testing decreased the concentrations of mercury, lead, and chromium in the TCLP extract by orders of magnitude. Despite the high water content, these grouts exhibited excellent leach resistance, with ${ }^{85} \mathrm{Sr}$ and ${ }^{137} \mathrm{Cs}$ leachability indexes in excess of 9 , with the grout made from the actual sludge being considerably more leach resistant than the surrogate. Grout properties are a function of composition, but remain within the performance criteria for any variations anticipated for field application. 



\begin{abstract}
The cold demonstration test proved that less water was required to pump the in situ grout formulation than had been previously tested in the laboratory. The previous in situ grout formulation was restandardized with the same relative amounts of dry blend ingredients, albeit adding a fluidizing admixture, but specifying less water for the slurry mix that must be pumped through the nozzles at high pressure. Also, the target GAAT tank for demonstrating this in situ grouting technique has been shifted to Tank TH4. A chemical surrogate sludge for TH4 was developed and tested in the laboratory, meeting expectations for leach resistance and strength at $35 \mathrm{wt} \%$ sludge loading. In addition, a sample of hot TH4 sludge was also tested at $35 \mathrm{wt} \%$ sludge loading and proved to have superior strength and leach resistance compared with the surrogate test.
\end{abstract}




\section{INTRODUCTION}

The Gunite and Associated Tanks (GAAT) were constructed at Oak Ridge National Laboratory (ORNL) between 1943 and 1951 and were used for many years to collect radioactive and chemical wastes generated by ORNL operations. These tanks are currently inactive and have not been used to collect these waste solutions and sludges for many years. Much of the sludge accumulated in these tanks was removed and disposed via the Hydrofracture Program. In addition, a project is currently under way to move the remainder of this sludge and supernatant to the Melton Valley Storage Tanks (MVST) for solidification and disposal with other ORNL tank sludges. The robotic apparatus being used for this removal did not fit into the smaller TH4 tank, so in situ grouting was proposed to demonstrate closure of this tank. The GAAT sludges contain a high amount of radioactivity (mainly ${ }^{90} \mathrm{Sr}$ and ${ }^{137} \mathrm{Cs}$ ). Some RCRA metal concentrations are high enough in the available total constituent analysis for the GAAT sludges to be potentially RCRA hazardous (the GAAT sludges have been found characteristically hazardous for mercury via TCLP); therefore, these sludges are presumed to be mixed waste.

Grouting and vitrification are currently the most likely stabilization/solidification alternatives for mixed wastes. Grouting has been used to stabilize/solidify hazardous and low-level radioactive waste for decades. Vitrification has been developed as a high-level radioactive alternative for decades and has been under development recently as a mixed-waste alternative disposal technology. In situ grouting of tank sludges via Multi-Point Injection ${ }^{1}$ (MPI, a patented, proprietary technique) is being investigated as a low-cost alternative to: (1) mobilization of these sludges to the Melton Valley Storage Tanks for later solidification and disposal; (2) ex situ grouting of these sludges, followed by either disposal back in the tanks or containerizing and disposal elsewhere; and (3) vitrification of the sludges. The usual disadvantage of volume increase by grouting does not apply in this case if the grout is disposed in place in the existing tanks (the current plan is to fill the tanks for structural stability and leave them in place whether the sludge is removed or stabilized in place). This technology is a potential candidate for treating 
the large quantities of sludges present on the other DOE sites (e.g., Hanford, Savannah River, and Idaho).

The current development effort builds on the previous work of developing a grout formulation for in situ grouting of the GAAT tanks. ${ }^{2}$ The dry blend developed in this effort was field tested in a cold demonstration at Duncan, Oklahoma. This field test established the composition of the jetting slurry that was still pumpable by the full-scale Halliburton pumps. The water content required for pumpability proved to be significantly less in this field test than had been surmised during the prior laboratory development. This field test established the target jetting slurry for further laboratory testing. This report documents the laboratory surrogate and hot testing of the field adjusted jetting slurry for in situ grouting of the TH4 sludge. The results targeted a $35 \mathrm{wt} \%$ loading of the TH4 sludge, calculated for in situ grouting of the sludge inventory during this work. Near the end of these tests, plans were changed to remove the sludge from TH4 and add it to the MVST inventory. The in situ grouting demonstration of TH4 is still currently planned, but only a tank heel would be incorporated into the grout at a loading far less than $35 \mathrm{wt} \%$. In general, this change should improve the grout properties.

\section{OBJECTIVE}

The objective of this project was to measure the properties of the TH4 grout formulation, after the adjustments made during the cold demonstration in the field of in situ grouting via MPI. This objective supports a proposed demonstration of in situ grouting of the TH4 sludge by MPI and is to be accomplished using a surrogate and an actual sample of the TH4 sludge. Another objective of the laboratory surrogate work was to test the performance at sludge loadings higher than the target of $35 \mathrm{wt} \%$, in an attempt to increase field flexibility and confidence. 


\section{SURROGATE}

The surrogate previously developed for in situ grouting of the GAAT tank sludges ${ }^{2}$ was adjusted to more closely represent the sample of TH4 sludge obtained for hot testing in this study. Table 1 lists the composition measured for this TH4 sludge sample and compares this measured composition to the surrogate sludge composition used in this prior work in FY 1996 and the surrogate sludge composition selected for the work documented in this report. Table 2 lists the compounds selected for the TH4 surrogate and their respective target concentrations. As stated, the major constituent concentrations of the prior surrogate were adjusted to more closely match that of the sludge sample. The actual sludge sample did not have a challenging RCRA metal composition; hence, the relative RCRA metal content (allowing for the difference in surrogate water content and the compositional adjustment to total $100 \%$ ) of the old surrogate was retained to challenge the stabilization potential of the grout. The RCRA metal content utilized in the old surrogate was representative of the maximum concentration previously characterized in all the GAAT tank sludges. In other words, the TH4 surrogate had a RCRA metal content representative of the maximum previously measured in all the GAAT tank sludges, far above the concentration measured in the TH4 sludge sample.

\section{SELECTION OF THE DRY-BLEND ADDITIVES}

The historical inorganic additives used for stabilization/solidification are Portland cement, fly ash, lime, and clay, but also include blast furnace slag, cement kiln dust, high-alumina cements, natural pozzolans, masonry cements, special cements, and cement admixtures. ${ }^{3,4}$ Conner cites the following reasons for the widespread use of these materials in treating wastes: ${ }^{3}$

- Relatively low cost

- Good long-term stability, both physically and chemically

- Documented use on a variety of industrial wastes over a period of at least 10 years

- Widespread availability of the chemical ingredients 
- Nontoxicity of the chemical ingredients

- Ease of use in processing (processing normally operated at ambient temperature and pressure and without unique or very special equipment)

- Wide range of volume increase

- Inertness to ultraviolet radiation

- High resistance to biodegradation

- Low water solubility

- Relatively low water permeability

- Good mechanical and structural characteristics

The International Atomic Energy Agency (IAEA) lists the following advantages and disadvantages of cement for the solidification of radioactive wastes: ${ }^{4}$

\section{Advantages}

- Material and technology well known;

- Compatible with many types of waste;

- Most aqueous wastes chemically bound to matrix;

- Low cost of cement;

- Good self-shielding;

- No vapor problems;

- Long shelf life of cement powder;

- Good impact and compressive strengths;

- Low leachability for some radionuclides;

- No free water if properly formulated;

- Rapid, controllable setting, without settling or segregation during curing. 


\section{Disadvantages}

- Some wastes affect setting or otherwise produce poor waste forms.

- $\mathrm{pH}$ adjustment of waste may be necessary.

- Swelling and cracking occur with some products when they are exposed to water.

- Volume increase and high density may develop.

- Excessive heat may develop during setting with certain combinations of cement and waste.

- Dust problems may occur with some systems.

- Equipment for powder feeding is difficult to maintain.

- Potential maintenance problems may result from premature cement setting, especially in the case of in-line mixers.

Portland cement, fly ash, Indian Red Pottery Clay (IRPC), ground granulated blast furnace slag, and bentonite were selected for use in this study. A brief history and reasons for these selections are presented in the following subsections for each material.

\subsection{PORTLAND CEMENT}

Portland cement, its composition, and its chemistry are discussed in great detail in several references and will not be discussed in detail in this report. ${ }^{3-9}$ The main points of interest for cement stabilization/solidification are the (1) normal high $\mathrm{pH}$ of cement matrices; (2) production of calcium hydroxide in normal cement hydration; and (3) strong binding matrix, resistant to advective water flow and leaching that interacts with and encapsulates the waste. Wastes are generally physically encapsulated heterogeneously in the calcium-silicate-hydrate (CSH) matrix, with the level of dispersion and homogeneity usually dependent on the energy and effort put into physically mixing waste and cement. Despite the inherent composite nature of cement waste forms, the wastes strongly interact with the cement, stabilizing contaminants as desired and sometimes interfering with cement hydration, which is not desired. Although there is evidence that some contaminants are incorporated into the CSH matrix, the main stabilizing mechanism of cement waste forms are the high-pH matrix, similar to the lime precipitation of metals in waste water treatment. 
This high-pH precipitation captures the majority of the RCRA metals and radionuclides. For example, the low solubility at high $\mathrm{pH}$ of copper, nickel, cadmium, zinc, silver, and lead are illustrated in the published solubility curves with $\mathrm{pH}^{3,10}$ In general, these solubility curves pass through a minimum as the $\mathrm{pH}$ increases, which means that these metals actually start becoming more soluble with $\mathrm{pH}$ past a certain point, with the generation of complex hydroxide ions. The minimum solubility for these metals occurs in a $\mathrm{pH}$ range from about 9 to slightly more than 11 . The normal production of calcium hydroxide during cement hydration and the presence of alkalis in the cement can produce a pore solution $\mathrm{pH}$ in the range of 12 to 13 , well above the minimum solubility for most of these metals. ${ }^{3}$ This combination (highmatrix $\mathrm{pH}$ and increasing metal solubility at this $\mathrm{pH}$ level) can actually increase the leachability of some wastes after treatment. This factor is one reason neat cement pastes (i.e., pastes consisting only of mixtures of cement and water) are a poor choice for stabilizing wastes and why cement-fly-ash combinations are almost always used. Fly ash consumes the calcium hydroxide produced during cement hydration, (1) moderating the matrix $\mathrm{pH}$ and (2) eliminating the large soluble Portlandite crystals (these crystals dissolve upon immersion, leaving large accessible pores in the matrix, increasing porosity and leachability) found in neat cement pastes. Cementitious waste forms (typically, cement-fly-ash) reportedly have a pH of about 11 , much better suited for minimizing metal solubility. ${ }^{11}$ The solubility behavior of the RCRA metals in cement waste forms mimics these solubility curves to a certain degree, but differs enough to illustrate that "... factors other than hydroxide precipitation are in operation...." 3,12

Cements are produced and sold in many forms, any of which may be suitable for stabilizing wastes. Portland cements are the most commonly available cements, typically available locally and cheap. The American Society for Testing and Materials (ASTM) standards specify five standard Portland cements with optional properties available within each type (ASTM C $150-89$ ): 3, 13

\section{ASTM-Type Portland Cement}

I

II

III

IV

\section{Description}

General-purpose Portland cement and usually the least expensive

Moderate sulfate resistance and moderate heat of hydration;

Type II-fly ash is typical substitute when job size can't justify Type IV production

High early strength and cold weather use Low heat of hydration, used in massive structures (e.g., dams) 
where temperature rise can approach adiabatic, generally not available, mass produced for specific jobs

Sulfate resistant

ASTM Type I Portland cement is most commonly used for waste stabilization because of its wider availability, lower costs, and its ability to work in most cases with proper tailoring. The way the ASTM specifications are written, ASTM Type II Portland cement can be considered a subset of ASTM Type I Portland cement and quite often cement is marketed as Type I-II Portland cement. If Type II Portland cement is available locally, it may be better to specify Type II because of its better sulfate resistance and lower heat of hydration (many wastes contain sulfate and the heat of hydration can be a concern for some waste form applications). In addition, specifying the options of low alkali (LA) and low alumina (if available) may be desirable to make the final waste form more resistant to later destructive expansion from minerals, such as alkali silicates, ettringite, or calcium chloroaluminate.

In summary, the best a priori cement selection may be ASTM Type II Portland cement-LA-low aluminamoderate heat of hydration. However, any of the cement types may be satisfactory for a given application, and such selections should be made on a case-by-case basis, depending on waste composition, cement availability, technical performance, and costs. In the present study, the main function of the cement selected was to ensure activation of the ground granulated blast furnace slag; hence, it was not necessary to specify the cement listed above since it would not provide the basic wasteform matrix. Type I, Type II, or Type I-II would be equally appropriate for this task, although Type II or I-II would still be preferred, if readily available, because of better sulfate resistance.

\subsection{FLY ASH}

Fly ash is an active pozzolan source that reacts with the caustic alkalis and alkalines, consuming hydroxide and producing alkali silicates and more CSH. Fly ash is only one of several possible pozzolans that can be used with cement or lime to produce cementitious waste forms. Other pozzolan candidates include volcanic glasses, volcanic tuffs, calcined clays and shales, diatomites, rice husk ash, volatilized silica (silica fume), blast furnace slag, and other slags. ${ }^{4}$ The key to the reactivity of the fly ash (and many of the other pozzolans) is its glassy structure. Only the amorphous glassy form provides a soluble silica source for reacting with the lime (and other caustics). The crystalline forms, like mullite, 
are too insoluble, stable, and inert. Fly ash was used in construction concrete decades prior to its use in waste disposal. $3,4,14-18$

Using fly ash in concrete has many advantages in certain usages, the most important being cost, as it replaces 25 to $35 \mathrm{wt} \%$ of the Portland cement normally used. ${ }^{3}$ Incorporating fly ash into cement lowers the heat of hydration, reducing curing temperature, an advantage in producing massive monoliths. ${ }^{9,}$ 19-23 Fly ash acts as both a pozzolan and a bulking agent, helping to prevent settling in relatively low-solids wastes and saving costs by substituting for cement. ${ }^{3}$ However, such bulking does result in larger volume and weight increases than for Portland cement alone, “... usually only justified where low handling, transportation, and disposal costs are encountered." ${ }^{.3}$ However, the relatively higher volume from fly ash is acceptable in its use as a pozzolan. Hydrating cement produces lime as a by-product that forms large soluble crystals in the cured neat cement paste matrix. These crystals dissolve upon immersion, leading to increased accessible porosity and leachability. Pozzolans react with this lime to produce more CSH to fill the available porosity, decreasing accessible porosity and leachability. In other words, fly ash "... helps to bind additional water, decrease the pore $\mathrm{pH}$, and act as an adsorbent for metal ions." 3

Since strontium behaves similarly to calcium, cement-pozzolans will also tend to tie up ${ }^{90} \mathrm{Sr}$ better than cement alone. Cement-fly ash has traditionally been the stabilizer of choice for ${ }^{90} \mathrm{Sr}$, although cement alone does stabilize ${ }^{90}$ Sr quite well. ${ }^{14,19-22}$

The ASTM standards specify two fly ashes and one natural or calcined pozzolan for use in Portland cement concrete (ASTM C 618 - 91): ${ }^{3,23}$

ASTM Mineral Admixture Class

$\mathrm{N}$

F

$\mathrm{C}$

\section{Description}

Raw or calcined natural pozzolans

Fly ash normally produced from anthracite or bituminous coal, has pozzolanic properties

Fly ash normally produced from lignite or subbituminous coal, has pozzolanic and cementitious properties, may contain lime $>10 \%$ 
In general, a commercial industry has evolved to supply fly ash cheaply and with adequate QA/QC to routinely meet ASTM standards, making a valuable by-product out of the large amounts of waste produced daily in the coal-fired power plants across the country. Although both can be and have been used, ASTM Class F fly ash is generally preferred for waste treatment, because of the possibility of "flash set" in the equipment with ASTM Class C fly ash. This difference in reactivity is indirectly related to the higher minimum specified content of silica, alumina, and iron oxide for Class $F(\geq 70 \mathrm{wt} \%$ ) compared with Class $\mathrm{C}$ ( $\geq 50 \mathrm{wt} \%)$. Although the lime content is not specified in the standard, a large fraction of the remaining composition is "free lime," which can lead to hydraulic cementitious reactions within the fly ash. Typically, the low lime content of Class F fly ash is quickly consumed, leaving the bulk of the fly ash relatively inert until caustically activated (e.g., by mixing with cement and the subsequent production of lime from hydration). Class $\mathrm{C}$ fly ash can contain lime concentrations as high as $30 \mathrm{wt} \%$ or higher, a highly reactive mix that can set into a cementitious product in a matter of minutes upon mixing with water ("flash set"). Because the lime content is not specified by the standard, the fly ash lime content varies from source to source and can vary from batch to batch. For these reasons, ASTM Class F fly ash was selected for this study.

\subsection{INDIAN RED POTTERY CLAY}

Over the years, illite (Indian Red Pottery Clay), $(\mathrm{OH})_{4} \mathrm{~K}_{\mathrm{x}}\left(\mathrm{Al}_{4} \mathrm{Fe}_{4} \mathrm{Mg}_{4} \mathrm{Mg}_{6}\right)\left(\mathrm{Si}_{8-\mathrm{x}} \mathrm{Al}\right) \mathrm{O}_{20}$, has become a proven standard additive in grout formulation development at ORNL for making cementitious waste forms more resistant to the leaching of ${ }^{137} \mathrm{Cs} .{ }^{20,21,24-26}$ Illite has been known as an effective selective sorbent for ${ }^{137} \mathrm{Cs}$ for decades. ${ }^{27-29}$ The gap between illite layers is apparently ideal to allow cesium ions to diffuse between the clay layers and essentially irreversibly trap these ions. Although there are other illitic sources (e.g., conasauga shale), Indian Red Pottery Clay (IRPC) is the most readily available commercial source. The standard recipe evolved into $8 \mathrm{wt} \%$ of IRPC in the dry blend of cementitious materials used to stabilize/solidify the waste liquids, solids, or sludges. The $8 \mathrm{wt} \%$ in the dry blend was far in excess of the stoichiometric amount needed to load the typical ${ }^{137} \mathrm{Cs}$ contamination found in the wastes into the clay, because even a waste with high gamma activity from ${ }^{137} \mathrm{Cs}$ has a quite low concentration of ${ }^{137} \mathrm{Cs}$ on a molar basis. The main reason for $8 \mathrm{wt} \%$ IRPC in the dry blend was to distribute enough IRPC throughout the waste form so that all of the ${ }^{137} \mathrm{Cs}$ had access to the IRPC and mass transport distances were minimized. This strategy has served well for many years as witnessed by 
the high ANSI/ANS-16.1 leachability indexes reported for ${ }^{137} \mathrm{Cs}$ over the years for grouts containing IRPC.

\subsection{GROUND GRANULATED BLAST FURNACE SLAG}

Blast furnace slag is a normal by-product of the iron and steel industry. In general, the slag is cooled in two ways (1) air cooling and (2) water quenching (granulation). Air cooling produces inert crystalline slag useful as an inert fill material, but useless as a cement substitute. The essential components of slag are the same oxides as are present in Portland cement, but "... for use as a cement, rapid cooling is necessary to quench the material to form a reactive glass and to prevent the crystallization of unreacted chemical compounds." 4 Granulated slag hydrates slowly on contact with water, but is activated by caustics (e.g., calcium hydroxide or sodium hydroxide), calcium sulfate, sodium carbonate, and sodium sulfate. ${ }^{4}$ The granulated slag is finely ground and marketed as a substitute for cement. The ground granulated blast furnace slags (slags) “... have physical properties similar to those of ordinary Portland cements. The distribution of particle size and the surface area of blast-furnace slags depend on the method of manufacture, but in general their fineness is similar to that of Portland cements.", 30

Slags have been substituted for cement for decades. ${ }^{31}$ Slags hydrate slowly to form CSH, the same product formed by cements, but slag alters the morphology and properties of the final product, sometimes in subtle ways, but beneficially in general: $:^{4,31-38}$

- early strength development is slower;

- heats of hydration are lower;

- $\quad$ sulfate resistance is improved;

- lower permeability despite increased total porosity;

- improved frost resistance;

- lower ionic diffusion rates;

- increased salt stability;

- reduced setting rate;

- extended working time;

- pore water contains sulfur species in addition to hydroxide anions;

- high $\mathrm{pH}$ and low oxygen potential; 
- reduced solubility of most contaminants;

- reduced rate of corrosion of steel containers; and

- other physical and mechanical properties similar to portland cements (e.g., density and compressive strength).

A slag:cement combination of 75:25 virtually eliminates calcium hydroxide as a hydration product (i.e., the presence of excess slag prevents build up of this cement hydration product). ${ }^{4}$ This implies that the proper proportion of slag-cement can replace cement-fly ash to stabilize ${ }^{90} \mathrm{Sr}$. In addition, a combination of 85:15 or higher slag produces a strong reducing environment within the matrix, suitable for reducing pertechnetates or chromates. ${ }^{39,40}$ Thus, slags have been used in grouts developed for radioactive and mixed wastes for a long time..$^{41-49}$

The ASTM standards specify three strength grades of ground granulated blast furnace slag for use in concrete and mortars based on the slag activity index: $:^{50}$

\begin{tabular}{ccc} 
ASTM Slag Grade & & \multicolumn{2}{c}{ Minimum Average Slag Activit } \\
\cline { 2 - 3 } 80 & $\underline{7 \mathrm{~d}}$ & $\underline{28 \mathrm{~d}}$ \\
100 & $\ldots$ & 75 \\
120 & 75 & 95
\end{tabular}

These slag grades are important for construction purposes, but not necessarily for waste treatment, where strength requirements are usually minimal. The chemical properties normally present in commercially available slag are their most important property for waste treatment and are generally not specified in the ASTM standard. Perhaps the most important property (Re: waste treatment) measured in the standard is the air permeability or Blaine fineness, although no limits are specified. ${ }^{51}$ Finer slag usually means a lower permeability, not only in the dry slag, but also in the resulting cementitious matrix. A lower permeability implies "... improved resistance to frost, lower diffusion rates of ions through the hardened cement and improved stability in the presence of salts, such as chloride and sulphate." 37 Typically, Portland cement has a Blaine fineness of 3000 to $4000 \mathrm{~cm}^{2} / \mathrm{g}$ and slag, of 4000 to $5000 \mathrm{~cm}^{2} / \mathrm{g}$, but slag $>5000 \mathrm{~cm}^{2} / \mathrm{g}$, or even $>6000 \mathrm{~cm}^{2} / \mathrm{g}$, can sometimes be acquired. In general, the finer, the better, although it is unlikely that special requests for finer grinding is worth the additional costs. Any commercially 
available slag suitable as a cement substitute generally improves the matrix properties and imparts the desired properties to the final waste form. Ground granulated blast furnace slag with a Blaine fineness of $>4000 \mathrm{~cm}^{2} / \mathrm{g}$ was selected for this study.

\subsection{WATER-SORPTIVE SUSPENSION AGENTS}

When a grout is poured and allowed to remain static, the binding and pozzolanic agents (cement, fly ash, slag) tend to settle, leaving a drainable liquid on the grout surface (phase separation, bleed water, freestanding liquid, or free water). ${ }^{52-54}$ Traditionally, two methods have been used to control this free-water generation: (1) increasing the solids-to-liquid mix ratio (or inversely decreasing the liquid, or water, to solids ratio W/S) and (2) adding gel clays. Gel clays disperse in water and form a thick, stable colloidal gel when mixing stops. This reaction prevents suspended particles, such as fly ash, cement, or slag, from settling while minimizing the dry blend added for treatment and the subsequent volume increase. The gel clays from oil field drilling fluids (muds) were adapted for this purpose in waste treatment grouts.

Water-sorptive clays have been used in geotechnical applications [e.g., construction (slurry walls and clay caps) and drilling (drilling muds and cement mixes)] for decades to resist solids segregation (suspension aid), prevent bleed water, and act as an engineered hydraulic barrier to water penetration (into a construction zone, waste disposal site, etc.). The most commonly used clay for these purposes is bentonite, sodium montmorillonite, “... a colloidal clay mined in Wyoming and South Dakota. It imparts viscosity and thixotropic properties to fresh water by swelling to about 10 times its original volume. Bentonite (or gel) was one of the earliest additives in oil-well cements to decrease slurry weight and to increase slurry volume." 55,56 The individual clay particles of bentonite are plate-shaped. The particle faces are positively charged; the edges are negatively charged. When mixed with water, the platelets separate and disperse throughout the fluid. When mixing ceases, the clay particles form a multilayered colloidal gel structure caused by the attraction of opposite charges. However, the electrostatic doublelayer forces are lessened with increasing ionic strength. ${ }^{54,57}$ Consequently, high-salt solutions (notably chloride, sulfate, and phosphate salts, as well as acids and bases) collapse these gels, lessening their dispersive effectiveness and releasing the large volume of water collected around the clay particles (i.e., free water can form if salt solutions are grouted). ${ }^{54,58}$ 
This susceptibility compromised the use of bentonite in off-shore oil drilling in salty waters. For this reason, attapulgite was adapted as the gel clay used in such salty applications, because attapulgite clay particles carry no charge and are not affected by high salt content. ${ }^{54}$ The individual attapulgite particles resemble needles, rather than platelets. When mixed with water, these needles are dispersed throughout the fluid and become aligned along shear planes. When mixing ceases, a gel structure is formed by the random entanglement of these particles, referred to as a "brush-heap effect." Attapulgite is commercially available only from northern Florida and southern Georgia. ${ }^{54}$ Thus, attapulgite has been adopted as the gel clay of choice for salty wastes. Note that although several forms of attapulgite have been tested for DOE salty wastes, only attapulgite 150 (Attagel 150) proved effective. ${ }^{54,59}$

The American Petroleum Institute (API) has issued specifications for both bentonite and attapulgite..$^{60,61}$

\section{EXPERIMENTAL}

\subsection{SURROGATE PREPARATION}

The surrogate $\mathrm{TH} 4$ wet sludge was prepared from reagent-grade chemicals according to the composition listed in Table 2. The chemicals were allowed to hydrolyze in the recipe water for at least 20 min prior to use.

\subsection{BLENDING}

The dry powders used to make the jetting slurries and grouts consisted of the following: (1) ground granulated blast furnace slag (slag), (2) Portland cement (cement), (3) Class F fly ash (fly ash), (4) Indian Red Pottery Clay (IRPC), (5) bentonite clay (bentonite), and Halliburton's fluidizing admixture (CFR-3). All of these ingredients were supplied by Halliburton from the cold field demonstration. The quantitiy of the Halliburton slag was insufficient for the sensitivity tests, so another slag from Holnam was substituted in the sensitivity tests

The slag, cement, fly ash, IRPC, and CFR-3 were blended together. The bentonite was prehydrated for 1 to $2 \mathrm{~h}$ in the water used to prepare the jetting slurry. The dry blend was mixed with this bentonite slurry to make the jetting slurry (slurry to be jetted into the sludge in the field, mixing it into the final 
grout). The dry blend either came from a sample of dry blend prepared in the field demonstration or from a laboratory blend of the individual ingredients. The dry blends prepared in the laboratory were blended for $2 \mathrm{~h}$ in an 8-qt twin-shell blender (or V-blender) from the Patterson-Kelley Co.

\subsection{MIXING}

The grouts were too thick to mix with a Waring-type blender and were mixed in a Model N-50 Hobart mixer using a flat blade, low shear compared to field mixing, pumping and jetting. The mixing was done in three steps: (1) prehydration of the bentonite in water (bentonite gel slurry), (2) the bentonite gel slurry and dry blend were mixed (jetting slurry) and (3) the jetting slurry was mixed with the surrogate sludge. In the field, the jetting slurry must be pumped into the grouting lances and through the jet nozzles into the sludge, meaning the rheology of this mix is important (slurries too viscous cannot be pumped). In the original grout development, the jetting slurry rheology was controlled, but the cold field operation demonstrated that thicker slurries could be pumped and jetted, too thick to measure by Fann viscometer. (The criterion in the original development was a Fann reading of about 150 at 600 RPM, the field thickness was off-scale, $>300$ at 600 RPM.) Although some laboratory Fann viscometer readings were taken to confirm this field observation, the control property for proper formulation was the density of the jetting slurry. The jetting slurry was consistently maintained at $14.5 \mathrm{lb} / \mathrm{gal}$ via a field density meter during the cold field demonstration.

Prehydration of bentonite was usually accomplished by soaking in water $1-2 \mathrm{~h}$ prior to mixing the jetting slurry. The procedure for generating leach samples spiked with radionuclides consisted of spiking the surrogate sludge with the radionuclides, mixing in the Hobart for a few minutes, allowing equilibration for $20 \mathrm{~min}$, mixing with the dry blend and jetting water into a grout, casting grout leach cylinders in the Teflon ${ }^{\mathrm{TM}}$ mold sealed at the bottom with silicone caulk, and curing for $28 \mathrm{~d}$ under humid conditions.

\subsection{CURING}

The freshly made grout was cured at room temperature in a sealed container in humid conditions. The samples were cured the standard $28 \mathrm{~d}$ for the sensitivity testing. 


\subsection{PERFORMANCE TESTING}

The performance testing for the sensitivity tests consisted of measuring the density, 28-d unconfined compressive strength, 28-d free water, 28-d TCLP performance, and the $28-\mathrm{d}$ leachability index of ${ }^{85} \mathrm{Sr}$ and ${ }^{137} \mathrm{Cs}$. The rheology of some jetting slurries was measured with a $35 \mathrm{~A} / \mathrm{SR} 12$ Fann $^{\mathrm{TM}}$ viscometer.

The free water was measured by casting $250 \mathrm{~mL}$ of grout into a graduated cylinder and measuring the volume of free water standing over the solid grout. This property is reported as vol \% calculated by dividing the observed free-water volume in $\mathrm{mL}$ by $250 \mathrm{~mL}$ and multiplying by 100 .

The density of the freshly mixed grout was obtained by measuring the net mass in $\mathrm{g}$ of the $250 \mathrm{~mL}$ of grout in the free-water test and dividing by $250 \mathrm{~mL}$ to obtain the density in units of $\mathrm{g} / \mathrm{mL}$. The density of the surrogate sludge was also obtained using a graduated cylinder.

For the unconfined compressive strength, nominal 2-in. cubes of grout were cast and cured. After curing $28 \mathrm{~d}$, the cube dimensions were measured and the force $\left(\mathrm{lb}_{\mathrm{f}}\right)$ required to crush the cube was measured on a Boart Longyear Machine. Dividing the crushing force by the cube cross-sectional area gave the unconfined compressive strength (psi).

A modified TCLP test was performed on the grout samples after curing for $28 \mathrm{~d}$ in humid conditions. The modified procedure extracts a $10 \mathrm{-g}$ sample with $200 \mathrm{~mL}$ of extractant, rather than the standard $100-g$ extraction with $2 \mathrm{~L}$ of extractant. The more aggressive TCLP fluid No. 2 was specified for the extraction, without the standard $\mathrm{pH}$ testing. After extracting $18 \mathrm{~h}$, the undissolved solids are filtered from the extract. The concentrations of the inorganic RCRA metals, except mercury, in the extract were then measured using a Thermo Jarrel Ash ICAP 61E Trace Analyzer (ICP). Although selenium and arsenic analyses by ICP are not usually accepted, EPA accepts the higher sensitivity of the 61E. The concentration of mercury in the TCLP extract was measured with a Leeman Labs PS 200 cold-vapor atomic absorption (CVAA) mercury analyzer. The only RCRA metals included in the GAAT surrogate were mercury, lead and chromium, so only these concentrations are reported in the results.

For the leachability index, a semidynamic leach test was performed on grout samples spiked with ${ }^{137} \mathrm{Cs}$ and ${ }^{85} \mathrm{Sr}$ and cured for $28 \mathrm{~d}$ in humid conditions using a modification of the ANSI/ANS-16.1 test. (In a 
semidynamic test, the samples remain quiescent in the leachate for a set time interval and are then moved to a fresh leachate at zero concentration for the next time interval.) The grout samples were leached in deionized water. The concentration of the radionuclides were measured by gamma spectroscopy using a germanium detector with an efficiency of $10 \%$ and a background of 30 counts per $1000 \mathrm{~s}$ or 0.03 counts per second (cps). After a 30-s rinse, the leachates were changed at cumulative times of $1,2,3,4$, and $7 \mathrm{~d}$. The effective diffusion coefficient was estimated from the cumulative fraction leached with timeassuming diffusion controlled leaching. The leachability index is the negative of the logarithm of the effective diffusion coefficient.

\section{RESULTS}

The experimental work consisted of two phases: scope testing and sensitivity testing. The scope testing checked the nominal field recipe of the jetting slurry, adjusted this recipe in the laboratory to attain the desired properties, and checked grout performance at the target loading of $35 \mathrm{wt} \%$ plus higher sludge loadings. After establishing the standard jetting slurry and grout, the proposed in situ grout formulation was subjected to sensitivity testing to variations in the formulation and surrogate composition.

\subsection{SCOPING TESTS AND FINAL SELECTION}

The formulation tested in the cold field demonstration was developed in the laboratory for all the GAAT tank sludges. ${ }^{2}$ The capability of testing the pumpability of the jetting slurry during this laboratory development was limited (i.e, the minimum water content required to make the jetting slurry pumpable, a critical parameter). Thus, one of the purposes of the field work was to ascertain the maximum thickness (rheologically) of jetting slurry that was still pumpable using the powerful Halliburton pumps. This demonstration established the pumpability of a jetting slurry far thicker than was tested in the laboratory. In fact, the previous measure of a Fann viscometer reading at 600 RPM was not measurable and off-scale $(>300)$. This measure was confirmed in the current laboratory testing (i.e., the jetting slurries documented in this report had Fann readings $>300$ at 600 RPM). The demonstration monitored the jetting slurry density during operation, consistently pumping and jetting at a density of $14.5 \mathrm{lb} / \mathrm{gal}$. The scoping tests attempted to confirm this property for the nominal field recipe using both the sample of the field blend and a laboratory blend of the field ingredients. 


\subsubsection{Jetting Slurry Adjustment}

Table 3 lists the compositions tested during these tests of the jetting slurry. These slurries were never mixed with the surrogate sludge. Tables 4 and 5 list the measured properties of these jetting slurries. Table 4 lists the densities measured using a mud balance and using a graduated cylinder. The mud balance values were consistently lower than those for the graduated cylinder. The graduated cylinder was judged to give results more consistent with the appearance and feel of the jetting slurry compared to the field operation and was selected as the measurement of choice.

ISG 1 and 2 were made according to the nominal field recipe, with the former using the field preblend and the latter using a laboratory blend. These slurries were subjectively judged to be thinner than the field slurry and the measured densities confirmed densities lower than the target of $14.5 \mathrm{lb} / \mathrm{gal}$. ISG 3 and 4 adjusted the composition to attain the desired slurry consistency and density. Basically, the relative amounts of dry additives, including bentonite, were established in the prior laboratory work. The field work established the slurry thickness that could be pumped. In these laboratory scoping tests, the jetting slurry water content was adjusted to mimic the thickness of the jetting slurry observed in the field. In other words, the adjustments simply entailed adding less water to the same relative amounts of dry ingredients. ISG 4 exhibited both the desired consistency and density using the laboratory blend, which accurately reflected the proper blend of dry ingredients. Next, the adjusted recipe was confirmed by duplicate runs using the field preblend, ISG 5 and 6 . ISG 7 confirmed that significantly increasing the bentonite content would make a slurry considerably thicker, apparently too thick to pump.

The jetting slurry sets into a fairly strong product, if allowed to cure without mixing with a sludge (see Table 5). It develops a compressive strength of $>2000$ psi in $<10 \mathrm{~d}$ and $>4000$ psi in a standard 28 -d cure. These laboratory strengths were significantly greater than the compressive strengths measured for field jetting slurry samples (about $2000 \mathrm{psi}$ ).

In summary, the water content of the nominal field recipe had to be decreased, and ISG 4-6 represent the target-jetting slurry composition for further testing and in situ grouting. 


\subsubsection{Scope Testing with Surrogate TH4 Sludge}

Table 6 lists the composition of grouts made using the selected jetting slurry at surrogate sludge loadings of 35,50 , and $65 \mathrm{wt} \%$. The target loading for in situ grouting of the TH4 sludge is $35 \mathrm{wt} \%$.

Tables 7-11 list the performance of these grouts. The volume increases 132,75 , and $38 \mathrm{vol} \%$ at sludge loadings of 35,50 , and $65 \mathrm{wt} \%$, respectively. Table 8 demonstrates that this formulation does an excellent job of keeping the solids suspended, not allowing phase separation and bleed water generation. Only the $65 \mathrm{wt} \%$ sludge loading had any bleed water, and only $1.2 \mathrm{vol} \%$ then for a grout with a fairly high water-to-solids ratio. Not unexpectedly, the grouts with the higher sludge loadings were fairly weak, and they did not develop a measurable penetration resistance in 7 days. They remained soft after $28 \mathrm{~d}$ at $65 \mathrm{wt} \%$ sludge and developed a compressive strength of only about $200 \mathrm{psi}$ at $50 \mathrm{wt} \%$ loading. The $35 \mathrm{wt} \%$ loaded grout was surprisingly strong with a 28 -d compressive strength of about $1800 \mathrm{psi}$, compared with that of about $500 \mathrm{psi}$ in the previous laboratory development. Obviously, the lower water content improved the strength significantly. Treating the surrogate sludge with this jetting slurry greatly improved the TCLP performance, but the highest sludge loading failed to meet the Universal Treatment Standards (UTS) for chromium.

\subsection{SENSITIVITY TESTING}

Sensitivity testing is the evaluation of the sensitivity of a selected formulation to changes in waste composition and changes in concentration of the grout composition. Table 12 lists the grout compositions tested during the sensitivity testing. The standard grout formulation listed in Table 12 is

TH4-1 and in addition to a wet sludge loading of $35 \mathrm{wt} \%$ more water was added to represent supernatant over the sludge during the in situ grouting. TH4-2-5 vary the grout composition, taken from among all the possible $\pm 10 \%$ variations in composition. TH4-6 and 7 tested the standard grout formulation while varying the surrogate sludge composition. The surrogate sludge was already representative of the maximum bad actors, so only the water content was varied with TH4-6 representing the maximum water content previously measured in the sludges and TH4-7 representing the minimum water content previously measured in the sludges. In addition to these variations around the standard grout formulation, two other grouts were tested during the sensitivity testing: TH4-8 and 9. TH4-8 tested a 50 wt \% sludge loading, as opposed to the target of $35 \mathrm{wt} \%$ and TH4-9 tested the standard grout 
formulation without fly ash (the fly ash fraction in the recipe was replaced with slag). This latter variation was to test the ${ }^{90} \mathrm{Sr}$ stabilization potential of cement-slag without fly ash.

Tables 12-18 list the results of this sensitivity testing. Table 13 indicates that a volume increase of about $130 \mathrm{vol} \%$ over the original sludge and supernate volume can be expected from in situ grouting of TH4. The volume increase for the grout composition variations ranged from 126 to 139 vol \%. A wet sludge water content representative of the maximum previously measured may lead to a volume increase of 160 vol \%; whereas, the minimum sludge water may lead to an increase of only $106 \mathrm{vol} \%$. A sludge loading of $50 \mathrm{wt} \%$ reduces the volume increase to about $78 \mathrm{vol} \%$. Removing fly ash from the formulation may lead to a volume increase of only $103 \mathrm{vol} \%$.

Four of the grouts experienced bleed water, but only the grout with $50 \mathrm{wt} \%$ sludge loading still had bleed water after a 28 -d cure, and this bleed water was only $0.2 \mathrm{vol} \%$, meeting the typical performance criterion of $<0.5 \mathrm{vol} \%$.

Treatment significantly improved the TCLP performance, and all the grouts met UTS limits, including that with $50 \mathrm{wt} \%$ sludge loading and minimum sludge water. The leachability indices ranged from 8.7 to 9.5 and 10.0 to 11.3 for ${ }^{85} \mathrm{Sr}$ and ${ }^{137} \mathrm{Cs}$, respectively, well above the $\mathrm{NRC}$ recommended value of 6.0. The ${ }^{85} \mathrm{Sr}$ leachability index without fly ash (TH4-9) compares well with the other grouts, indicating that cement-slag grouts are a suitable substitute for the cement-fly ash grouts traditionally used to stabilize ${ }^{90} \mathrm{Sr}$.

Although the grouts were firm, four-TH4-2, 4, 7, and 8-were relatively weak, with little or no penetration resistance and too soft to measure their compressive strength after the 28 -d cure. Because of concerns raised about the weakness of these samples, their penetration resistance was evaluated again after $72 \mathrm{~d}$. TH4-2 and 4 had developed measurable penetration resistances of 880 and 320 psi, respectively. These penetration resistances imply compressive strengths of about 20 to 50 psi, but this could not be confirmed with objective measurements. TH4-7 and 8 were still soft and crumbly. These results were unexpected. Although grouts 2 and 4 were weaker in a similar sensitivity test done in the previous laboratory work, the difference was not as dramatic. Grout 7 was tested using the minimum sludge water content, implying the higher amount of sludge solids may be weakening the physical matrix. Grout 8 was expected to be weaker since it contained a significantly higher sludge loading, $50 \mathrm{wt} \%$; 
however, it does not agree well with the physical strength observed for the scoping grout, Grout ISG-2 in Tables 6-11, which also had a sludge loading of $50 \mathrm{wt} \%$. For comparative purposes, the penetration resistance of this grout after $85 \mathrm{~d}$ was $5160 \mathrm{psi}$, implying a compressive strength of about $260 \mathrm{psi}$, consistent with the compressive strength of 209 psi measured after curing $40 \mathrm{~d}$. Thus, it appears that these grouts are slowly developing strength, which is not inconsistent with the known slow hydration of slag compared with cement. Caustic activation will significantly increase the rate of strength growth of slags, if this property is of importance. The two most noticeable differences between these two $50 \%$ loaded grouts was the higher water content of the sensitivity grout and the fact that a different slag was substituted for the Halliburton slag in the sensitivity grout. It is possible that either may account for the observed differences, but there is currently not enough information available to draw this conclusion. The two slags in question are being evaluated for any dramatic differences.

Table 19 lists the total concentration measured for each slag, using dissolution by aqua regia with hydrofluoric acid and boric acid followed by ICP analysis. (Because the preparation procedure added a large amount of boron to the dissolved slag, the resulting large boron concentration was not included in Table 19.) Although there are significant differences in the iron, magnesium, manganese, titanium, potassium, sodium, and zirconium concentrations, the major slag constituents of silicon, calcium, and aluminum are reasonably comparable. Of the former group, only magnesium could be considered more than a minor constituent. In addition, both slags were evaluated by X-ray diffraction (XRD), energy dispersive X-ray microanalysis (EDX), and optical microscopy. Comparisons of the diffractograms and the EDX spectra do not show any significant difference between the two samples. The diffractograms and EDX spectra are in the appendix. The diffractograms show that both samples are largely amorphous, as expected for granulated slag. The EDX elemental analysis indicates that both samples contain aluminum, calcium, copper, iron, potassium, magnesium, manganese, sulfur, silicon, titanium, and zinc in roughly the same amounts and in similar proportions. Optical analysis does show a difference between the slags. Optically, the Halliburton slag appears to consist of smaller glass particles and larger crystalline particles than the Holnam slag. Smaller glass particles would be consistent with a faster rate of hydration and quicker strength development, but it is not conclusive that these observed differences caused the observed difference in grout performance. Further evaluation continues, including scanning electron microscopy (SEM) and X-ray dot mapping. 
Note that all of these grouts stabilized the hazardous metals and radionuclides and the main difference observed in performance was the physical strength of the matrix. Furthermore, there were no strength criteria in the grout development. Basically, the grout will perform as well as or better than a loose flowable fill to fill the tank volume and support the walls and top. Based on the performance of the standard target formulation, a compressive strength of at least several hundred psi can be expected from in situ grouting of TH4, confirmed by the results from the hot testing of the actual TH4 tank sludge sample. If a more stringent physical criterion is desired, the grout can be reformulated.

\subsection{HOT TESTING WITH A SAMPLE OF THE TH4 SLUDGE}

A sample of the TH4 sludge was obtained for hot testing the in situ grouting formulation. Photographs of this sludge sample are illustrated in Fig. 1. Table 20 lists the total concentrations measured for this hot sludge sample. This hot sludge was mixed with the jetting slurry at a loading of $35 \mathrm{wt} \%$, cured for $28 \mathrm{~d}$ under humid conditions, and performance tested. Tables 19 and 20 list the performance test results of this grout. The grout density was significantly greater than for the comparable sensitivity grout (TH4-1 in Table 13), but was closer to the $35 \mathrm{wt} \%$ loaded scoping grout (ISG-3 in Table 7), $1.58 \mathrm{~g} / \mathrm{mL}$ for the hot grout compared with 1.43 and $1.50 \mathrm{~g} / \mathrm{mL}$ for the sensitivity and scoping grouts, respectively. Unlike the hot grout and scoping grout, the sensitivity grout included extra water for the supernatant. No bleed water developed, as in the surrogate testing. The hot grout developed a penetration resistance of only $80 \mathrm{psi}$ in $4 \mathrm{~d}$. Apparently hydration accelerated after $4 \mathrm{~d}$ because the penetration resistance was $2560 \mathrm{psi}$ after $7 \mathrm{~d}$. The sensitivity grout was significantly weaker at $7 \mathrm{~d}$ at only $800 \mathrm{psi}$, but the scoping grout was significantly stronger at 4000 and 5600 psi at 5 and $7 \mathrm{~d}$, respectively. The compressive strength of the hot grout was only 194 psi at $7 \mathrm{~d}$, but increased to 1365 psi at $28 \mathrm{~d}$. This is significantly stronger than the sensitivity grout of 581 psi at $28 \mathrm{~d}$. On the other hand, the scoping grout was considerably stronger at $7 \mathrm{~d}(824 \mathrm{psi})$. In TCLP testing, the untreated TH4 sludge sample essentially met the UTS limits, so it is not surprising that the treated sample sludge (grout) also met these limits (the thallium detection limit was higher than the UTS limit, so it is unclear for this underlying hazardous constituent). The leachability index of the hot grout was 13.5 and 10.6 for ${ }^{89 / 90} \mathrm{Sr}$ and ${ }^{137} \mathrm{Cs}$, respectively. The ${ }^{137} \mathrm{Cs}$ leachability index was comparable with that of the sensitivity grout at 10.8 , but was considerably higher for radioisotopic Sr with 9.1 for the sensitivity grout. These values indicate an improvement of four orders of magnitude in leach resistance for the radioisotopic $\mathrm{Sr}$ for the hot grout over the sensitivity grout, implying that the radioisotopic strontium is present as a less leachable species 
in the hot sludge than was used for the surrogate sludge. This conclusion is reasonable and means that the surrogate testing was even more conservative than anticipated.

\section{DISCUSSION OF THE RESULTS}

\subsection{TH4 SURROGATE VARIATION}

Most of the TH4 surrogate used during the sensitivity testing was representative of the most probable sludge in Tank TH4. The waste loading of $35 \mathrm{wt} \%$ was based upon current sludge thickness (30 in.) in the tank and maximum freeboard of about $48 \mathrm{in}$. The water content ( $66 \mathrm{wt} \%)$ of the sludge was based upon measurements of actual sludge taken from TH4. The variation of the waste loading and water content of the sludge can be examined by reviewing the data plotted in Fig. 2. For this discussion, 1S-9S refer to the nine grouts in the sensitivity tests and $1 \mathrm{DB}-3 \mathrm{DB}$ refers to the three grouts in the scoping tests, with $1 \mathrm{DB}, 2 \mathrm{DB}$, and $3 \mathrm{DB}$ representing sludge loadings of 35,50 , and $65 \mathrm{wt} \%$, respectively (i.e., ISG Nos. 3, 2, and 1 in Table 6, respectively). Most sludge data (8 of 12 tests) are clustered around a single point, $35 \mathrm{wt} \%$ waste loading and $66 \mathrm{wt} \%$ water content. This is the most likely sludge condition in Tank TH4. Four extreme sludge types were examined during the sensitivity studies:

1. Sample $6 \mathrm{~S}$ at $35 \mathrm{wt} \%$ waste loading and $85 \mathrm{wt} \%$ water content was selected to represent the highest-water-content sludge ever measured on a GAAT Farm sludge sample. This sludge represents a diluted sludge when compared with the surrogate TH4 sludge.

2. Sample $7 \mathrm{~S}$ is at the lowest water content of $35 \mathrm{wt} \%$ and $35 \mathrm{wt} \%$ waste loading. This sample represents a sludge with concentrated solids, at the extreme for the entire GAAT Farm.

3. Sample $8 \mathrm{~S}$ and $2 \mathrm{DB}$ are superimposed over each other on Fig. 2 at a water content of 66 wt $\%$ and waste loading of $50 \mathrm{wt} \%$. This sludge waste loading would occur if there was less freeboard in Tank TH4, or there was a major failure in the field pumping equipment. Both situations are easily controlled or verifiable in the field, and therefore, are a remote possibility.

4. Sample $3 \mathrm{DB}$ represents the highest waste loading attempted during the current work $-65 \mathrm{wt} \%$ waste loading and $66 \mathrm{wt} \%$ water content. 
The other difference between the nine sensitivity test samples (1S-9S) and the specimens made with the Halliburton dry blend (1DB-3DB) is that there was a small amount of surrogate supernatant (water) introduced into the sensitivity test samples.

\subsection{DRY SLUDGE AND LEVELS OF TREATMENT IN THE TH4 MONOLITH}

The percentage of dry sludge in each of the 12 mixtures was plotted in Fig. 3 vs the water-to-pozzolan ratio (W/P). The W/P ratio was selected since it represents the concentration of the treatment agents within the monolith. A low W/P ratio $(<1.0)$ indicates more concentrated treatment agents in the monolith, when compared with a high value $(>1.75)$.

Because the behavior of treated sludge is strongly influenced by the concentration of the contaminants and level of treatment, a clearer analysis of the data can be performed if the samples are grouped into categories with similar sludge loading and treatment. Examination of the data in Fig. 3 produced the following four groupings:

1. Most probable sludge solids and most probable level of treatment,

2. Most probable sludge solids and lower degree of treatment,

3. Concentrated sludge solids and lower degree of treatment, and

4. Concentrated sludge solids and lowest degree of treatment.

Each of these are discussed in the following subsections.

\subsubsection{Most Probable Sludge Solids and Most Probable Level of Treatment}

The data in Fig. 3 for sample number 1 DB represent the most likely combination of dry sludge solids (18 wt \%) and concentration of treatment, W/P ratio of 0.90 , which will be formed in Tank TH4 from in situ grouting. Sample $3 \mathrm{~S}$ essentially is the same as IDB with the only exception being the type of slag used in the preparation. Sample 1DB was made from the bulk blended dry blend prepared by Halliburton during the cold tank demonstration. Sample $3 \mathrm{~S}$ was prepared with the Holnam slag. 
Samples 1DB and 3S represent the most probable situation for Tank TH4. Many variables have been eliminated as unknowns:

1. Surrogate TH4 sludge contains more concentrated contaminants of concern than the actual tank sludge.

2. Measured water content was obtained on actual samples, as was the depth of supernatant.

3. Sludge loading of $35 \mathrm{wt} \%$ is ensured since freeboard in the tank is known, and field controls on MPI injection will ensure that gross levels of treatment agents are uniformly intermixed with sludge.

Although a sensitivity study usually examines a potential range around the most likely field situation, this method could not be used in this case. The ability to mix the viscous grout at more concentrated levels was not possible. Furthermore, the most concentrated grout was injected in the field and proved to be a successful formulation. The only variability that could be examined during the sensitivity study was having a more concentrated sludge at lower degrees of treatment.

\subsubsection{Most Probable Sludge Solids and Lower Degree of Treatment}

A total of 8 out of 12 samples (1S-6S, 9S, and 1DB) plotted in Fig. 3 contained about 18 wt \% dry sludge solids. Six of the samples had less treatment within the final mixture when compared with sample 1DB, while sample $3 \mathrm{~S}$ was nearly identical to $\mathrm{IDB}$. Therefore, when evaluating the performance of all 8 samples, the influence of the sludge solids can be eliminated. Any difference in the properties of the treated sludge can be linked directly to the level of the treatment or type of slag used.

\subsubsection{Concentrated Sludge Solids and Lower Degree of Treatment}

Two samples are at about $25 \mathrm{wt} \%$ dry sludge solids: 7S and 2DB. The treatment level for 7S is comparable to $1 \mathrm{DB}$ and $3 \mathrm{~S}$, whereas the concentration of pozzolan in the monolith is lower for sample 2DB. It would be anticipated that the level of treatment in sample 7S would provide for better performance than that represented by $2 \mathrm{DB}$. Again, the other difference between $7 \mathrm{~S}$ and $2 \mathrm{DB}$ is the type of slag used: 7S was prepared with the Holnam slag; $2 \mathrm{DB}$ was prepared with the slag purchased by Halliburton from Lone Star Cement (cold tank demonstration). 


\subsubsection{Concentrated Sludge Solids and Lowest Degree of Treatment}

The concentration of the dry sludge solids and high W/P ratio (lowest degree of treatment) for samples $8 \mathrm{~S}$ and 3DB plot at the most extreme levels for any data shown in Fig. 3. These two samples represent 25 to 33 wt \% sludge solids at low treatment levels (W/P of about 1.9) - about twice as much sludge solids with half as much treatment when compared with sample $1 \mathrm{DB}$, which is the most probable situation expected for in situ grouting TH4. Indeed, samples 8S and 3DB should have the lowest performance in terms of mechanical properties (strength). It will be shown that the mixtures for samples 8S and 3DB could immobilize the RCRA metals below TCLP treatment standards. Therefore, mechanical strength is not a good precursor for leach resistance.

\subsection{PERCENTAGE OF POZZOLAN IN MONOLITH}

The above groupings only provide a qualitative indication of the levels of treatment within the various grout/surrogate mixtures. The calculated percentage of pozzolan in the monolith will allow better quantification of the level of treatment to performance of the treated sludge. The percentage of pozzolan for the 12 mixtures are plotted in Fig. 4 vs the W/P ratio (these axes allow easier comparison between the two data sets in Figs. 3 and 4).

A linear relationship is shown in Fig. 4 between the percentage of pozzolan in the entire monolith and W/P concentration in the monolith. The linear correlation factor is $r=0.96$ for the data in Fig. 4 . The greatest amount of pozzolans ( $40 \mathrm{wt} \%$ ) in the monolith at the most concentrated levels $(\mathrm{W} / \mathrm{P}=0.9)$ occurs for samples $1 \mathrm{DB}$ and $3 \mathrm{~S}$. These data represent the most likely situation for the actual in situ grouting of Tank TH4.

All other data in Fig. 4 plot below $1 \mathrm{DB}$ and 3S. The other samples with the most probable sludge concentration (18 wt \%) vary in a decreasing order as: $5 \mathrm{~S}-9 \mathrm{~S}-1 \mathrm{~S}-6 \mathrm{~S}-4 \mathrm{~S}-2 \mathrm{~S}$. It is anticipated that the mechanical strength of these samples will vary directly as listed, with the possible exception of sample 9S. This mixture was prepared without fly ash, which should increase the strength over samples prepared with half slag and half fly ash. 
The two samples (7S and 2DB) with $25 \mathrm{wt} \%$ sludge solids contain slightly different levels of treatment, with sample $7 \mathrm{~S}$ having more pozzolan than $2 \mathrm{DB}, 37 \mathrm{vs} 31 \mathrm{wt} \%$, respectively. The mixture represented by $7 \mathrm{~S}$ should have a higher strength than sample $2 \mathrm{DB}$.

Samples 8S and 3DB have the highest amount of sludge solids and the lowest levels of treatment, with only about 25 wt $\%$ pozzolan within the monolith. These samples should have the lowest mechanical properties of any mixture tested.

\subsection{MECHANICAL STRENGTH AND LEACH RESISTANCE OF TREATED SURROGATE TH4 SLUDGE}

The main reason for performing treatment of the GAAT sludge is to prevent any future migration of the contaminants of concern out of the tank and into the environment. There are established Universal Treatment Standards (UTS) for the various RCRA metals. Mass Transport studies performed at ORNL indicate that the strontium and cesium can be immobilized for at least four half-lives (suggested design life of treatment), if the leachability index is on the order of about 10 or higher.

Criteria were not specified with respect to the strength of the grouted sludge. A strength function of the monolith would be to resist any future inward movement of the gunite tank walls. However, this does not require any shear strength related to cementation of the treated sludge. Merely having a consolidated monolith (solid) with a density above the unit weight of water would be adequate for long-term tank wall stability issues. The unit weights for all samples tested varied from a low of $1.27 \mathrm{~g} / \mathrm{mL}$ to a high of 1.65 $\mathrm{g} / \mathrm{mL}$, which is soil-like. Therefore, the tank walls would be structurally stable over the design life of the treatment.

The following sections discuss the results from measuring the unconfined compressive strength, leachability of RCRA metals, and leach resistance of the treated sludge.

\subsubsection{Unconfined Compressive Strength vs Levels of Treatment}

The unconfined compressive strength of the 12 grout/sludge mixtures was measured at various time intervals. The average values after 28 to $40 \mathrm{~d}$ of curing are plotted in Fig. 5 vs the W/P ratio. This 
evaluation of the data will use the grouping established above for the amount of sludge and treatment in the final mixture.

\subsubsection{Most Probable Sludge Solids and Most Probable Level of Treatment}

The data point $1 \mathrm{DB}$, representing the cold tank demonstration data in Fig. 5, has the highest unconfined strength at about 1,800 psi. Sample $3 \mathrm{~S}$ has only about half this strength ( $841 \mathrm{psi}$ ). The only major difference between these two samples was the type of slag used to prepare the specimens. The chemistry of these two slags was not examined during the bench-scale study. It would appear useful to examine the slag chemistry. Furthermore, guidelines should be developed for selecting the "most appropriate" slag for use during full-scale remediation.

\subsubsection{Most Probable Sludge Solids and Lower Degree of Treatment}

In a section above it was predicted that the rank ordering of the strengths of the samples with the $18 \mathrm{wt} \%$ dry-sludge solids would be: $3 \mathrm{~S}-5 \mathrm{~S}-9 \mathrm{~S}-1 \mathrm{~S}$, followed by $6 \mathrm{~S}-4 \mathrm{~S}-2 \mathrm{~S}$. The straight line drawn through these data points in Fig. 5 illustrates an inverse correlation with a high degree of confidence $(r=-0.95)$. The only sample that falls off the correlation line is 9S. Sample 9S was prepared without fly ash. Typically, equal amounts of fly ash and slag were used. The difference in mechanical strength between $1 \mathrm{~S}$ and $9 \mathrm{~S}$ is directly related to the increase in the slag in $9 \mathrm{~S}$. It appears that doubling the percentage of slag causes a doubling of the mechanical strength of the final mixture, from 580 to 1370 psi for $1 \mathrm{~S}$ and $9 \mathrm{~S}$, respectively.

\subsubsection{Concentrated Sludge Solids and Lower Degree of Treatment}

Since the relative amounts of dry solids for samples 7S and 2DB were similar (about 25 wt \%), it was believed that sample 7S would have a higher strength, since $7 \mathrm{~S}$ had more treatment in the final mixture, when compared with sample 2DB. As illustrated in Fig. 5, this prediction did not hold. Although sample $7 \mathrm{~S}$ consolidated into a cohesive mass, it did not achieve any measurable unconfined compression strength after $42 \mathrm{~d}$, (i.e., 0 psi strength). There are several possibilities for this occurrence, including: 
1. Mistakes were made in the laboratory during the preparation of sample $7 \mathrm{~S}$.

2. A problem does exist with the Holnam slag at $25 \mathrm{wt} \%$ dry solids and above. However, the Lone Star Cement slag used by Halliburton during the cold field demonstration was able to achieve $200 \mathrm{psi}$ strength $(2 \mathrm{DB})$, with less treatment (31 wt \% pozzolan) and more water (37 wt \%) in the final mixture than the corresponding values for sample 7S. The testing for sample $7 \mathrm{~S}$ should be repeated with Holnam and Lone Star Cement slag to verify the results.

It will be shown that sample $7 \mathrm{~S}$ was able to perform very well with respect to immobilizing the RCRA metals and producing a leach-resistant mixture for strontium and cesium. The immobilization of the contaminants of concern are the key performance requirements for the treatment of the sludge and can be accomplished by a soft consolidated mass with no cementation strength.

\subsubsection{Concentrated Sludge Solids and Lowest Degree of Treatment}

After $42 \mathrm{~d}$ the two samples (8S and 3DB) with the highest concentration of dry sludge solids and lowest amount of treatment did not achieve an initial set. The data plotted in the lower right-hand side of Fig. 5 are at 0 psi for these two data points.

The causes for no cementation strength developing could be related to the following:

1. More time (above $42 \mathrm{~d}$ ) is needed for the low concentration of solidification agents ( 20 to $25 \mathrm{wt} \%$ of the monolith composition).

2. Insufficient pozzolans in the mixture prevent an initial set. Two different types of slag were used, and neither slag produced an initial set.

Although there was no initial set of samples $8 \mathrm{~S}$ and $3 \mathrm{DB}$, they were both able to produce mixtures with good leach resistance. 


\subsubsection{TCLP Leach Test}

All 12 mixtures were subjected to TCLP leach tests. The untreated TH4 surrogate sludge was characteristically hazardous for chromium, lead, and mercury. The measured concentrations of these RCRA metals are listed in Fig. 6. All samples displayed in the figure had TCLP measurements below the listed UTS for mercury and lead. Note that there was a single data point for specimen 3DB in which chromium was slightly above the UTS limit of $0.86 \mathrm{ppm}$.

The other observation that can be extracted from Fig. 6 is that there is not a strong correlation between the measured unconfined compression strength and leach resistance of the mixtures against chromium, lead and mercury concentrations. Typical linear correlation factors were calculated at about $r=0.33$ for leach resistance vs compression strength.

The level of treatment applied to a sludge is directly proportional to the amount of improvement in the performance of the treated sludge (i.e., better leach resistance). This situation is precisely the case when the TCLP extract data are plotted vs the percentages of pozzolan in the final mixture. The data in Fig. 7 show a linear relationship $(r=0.8)$ for the reduction in chromium leaching vs the amount of treatment. Similar observations can be made for lead (Fig. 8).

More scatter is observed in the data about the regression line drawn through the mercury TCLP data, as shown in Fig. 9. However, all mixtures were able to immobilize the mercury below the universal treatment standard (UTS $=0.025 \mathrm{ppm})$. Furthermore, all the soft samples $(7 \mathrm{~S}, 8 \mathrm{~S}, 3 \mathrm{DB})$ had mercury leach resistance comparable to sample $3 \mathrm{~S}$, which had nearly twice as much pozzolan, $(3 \mathrm{~S}=40 \mathrm{wt} \%$ pozzolan in final monolith). The unconfined strength for sample $3 \mathrm{~S}$ was $841 \mathrm{psi}$, whereas samples $7 \mathrm{~S}$, $8 \mathrm{~S}$, and 3DB were soft, consolidated masses with 0 psi unconfined strength, (no cementation after $42 \mathrm{~d}$ ).

\subsubsection{ANSU/ANS-16.1 Leach Test}

The leachability indices for ${ }^{85} \mathrm{Sr}$ measured during ANS-16.1 tests are summarized in Fig. 10 vs the percentage of pozzolan contained in the specimens prepared for the sensitivity study. All the samples shown in Fig. 10 had leachability indices (L) between about 8.7 and 9.7. The most leach resistant 
$(\mathrm{L}=9.7)$ sample occurs for specimen $9 \mathrm{~S}$, which contained $50 \%$ slag in the grout $(0 \%$ fly ash). Sample 9S had a strength of about 1370 psi. Sample 7S, which had zero unconfined compression strength, had a measured leachability index $(D=9.5)$ nearly the same as $9 \mathrm{~S}$. The sample $8 \mathrm{~S}$ cylinder could not be recovered for leach testing. No ANS-16.1 Leach Tests were performed on samples 1DB, 2DB, or 3DB.

The leach resistance for ${ }^{137} \mathrm{Cs}$ is plotted in Fig. 11 vs the amount of pozzolan in the final mixture. All leachability indices were above 10 . The leach resistance of the specimens against the release of ${ }^{137} \mathrm{Cs}$ is dictated by the amount of IRPC clay in the mixture. All specimens plotted in Fig. 11 had IRPC contents of about $4 \%$ in the final mixture.

\subsection{HOT TESTING OF ACTUAL TH-4 SLUDGE SAMPLES}

The real test of how well the ORNL grout formulation works was revealed when the actual sludge from GAAT TH-4 was treated with the ORNL grout formulation. The dry blend mixed at the Halliburton bulk plant was used for the hot testing of the TH-4 sludge samples.

The results from the strength testing indicated that the grouted hot TH-4 sludge achieved an unconfined compression strength of 1365 psi after $28 \mathrm{~d}$. The results from TCLP extract analysis indicated that all RCRA metals were below the UTS standards for the treated sludge. As discussed in the results section, the ${ }^{137} \mathrm{Cs}$ leachability index was comparable with that measured for the surrogate, but increased by three for radioisotopic strontium $\left({ }^{85} \mathrm{Sr}\right.$ for the surrogate and ${ }^{89 / 90} \mathrm{Sr}$ for the hot test), implying an increase in leach resistance of three orders of magnitude for the actual sludge. The reason for this difference is unclear, because similar leach performance was expected for the different strontium isotopes. One surmise is that the hot sludge contained a less leachable strontium species than that used in the surrogate.

\section{SUMMARY AND CONCLUSIONS}

The sample formulation used during the cold field demonstration exhibited sufficient waste immobilization and physical strength characteristics throughout all phases of the 1998 bench-scale tests. The small amount of CFR-3 dispersant had no impact on the strength, leach and diffusion resistance of the samples tested. 
Large amounts (38 tons) of dry-blend material can be mixed at a bulk-blending facility and produce a dry blend with qualities similar to those measured on laboratory-scale samples (i.e., can uniformly blend large bulk samples for use during production remediation of Tank TH4).

In situ grouting of the TH4 sludge by MPI can produce grouts resistant to solids segregation with no free water that stabilize the RCRA metals within TCLP limits and provide excellent leach resistance for the radionuclides. This conclusion is backed by testing with a challenging surrogate of TH4 sludge and confirmed by testing with an actual sample of TH4 sludge. This tank sludge can be stabilized at a wet sludge loading of $35 \mathrm{wt} \%$, or higher, resulting in a volume increase of about $132 \mathrm{vol} \%$, with little or no secondary waste generation. The grout strength develops slowly, but is expected to exceed 1000 psi. The strength is sensitive to waste loading and pozzolanic content, but even the worst grouts tested were firm and strong enough to support anticipated overburdens. In situ grouting stabilizes the RCRA metals to meet TCLP criteria, including mercury, potentially a problem species for the tank sludges. The grout selected for sensitivity testing decreased the concentrations of mercury, lead, and chromium in the TCLP extract by orders of magnitude. Despite the high water content, these grouts exhibited excellent leach resistance, with ${ }^{85} \mathrm{Sr}$ and ${ }^{137} \mathrm{Cs}$ leachability indexes in excess of 9. Grout properties are a function of composition, but remain within the performance criteria for any variations anticipated for field application.

\section{ACKNOWLEDGMENTS}

The authors gratefully acknowledge the contributions of Mike Burgess (ORNL) and Bill Chase (ORNL) in sample preparation and performance testing and the support and guidance of Ben Lewis (ORNL), Dirk Van Hoesen (ORNL), Jacquie Noble-Dial (DOE-ORO), and the Tanks Focus Area of DOE. 


\section{REFERENCES}

1. Multi-Point Injection Demonstration for Solidification of Shallow Buried Waste at Oak Ridge Reservation, Oak Ridge, Tennessee, ORNL/ER-378, prepared by Ground Environmental Services, Inc., October 1996.

2. R. D. Spence and J. L. Kauschinger, Grout Performance in Support of In Situ Stabilization/Solidification of the GAAT Tank Sludges, ORNL/TM-13389, Oak Ridge Natl. Lab., May 1997.

3. J. R. Conner, Chemical Fixation and Solidification of Hazardous Wastes, Van Nostrand Reinhold, New York, 1990.

4. International Atomic Energy Agency, Improved Cement Solidification of Low and Intermediate Level Radioactive Wastes, Technical Reports Series No. 350, International Atomic Energy Agency, Vienna, 1993.

5. F. M. Lea, The Chemistry of Cement and Concrete, $3^{\text {rd }}$ ed., Chemical Publishing Co., Inc., New York, 1970.

6. I. Soroka, Portland Cement Paste and Concrete, Chemical Publishing Co., Inc., New York, 1979.

7. G. C. Bye, Portland Cement Composition, Production, and Properties, Pergamon Press, New York, 1983.

8. S. N. Ghosh, ed., Advances in Cement Technology Critical Reviews and Case Studies on Manufacturing, Quality Control, Optimization and Use, Pergamon Press, New York, 1983.

9. H. F. W. Taylor, Cement Chemistry, Academic Press, New York, 1990.

10. U.S. EPA, Federal Register, 52(155): 29999 (Aug. 12, 1987). 
11. Katherine M. Armstrong and Larry M. Klingler, "Evaluation of a Unique System for the Thermal Processing of Radioactive and Mixed Wastes," MLM-3340(OP), CONF-860223--1, proceedings of Conference on All Aspects of Low Level Waste, Chicago, Ill., Feb. 28, 1986 (1986).

12. P. Cote, Contaminant Leaching from Cement-Based Waste Forms Under Acidic Conditions, Ph.D. Thesis, McMaster Univ., Hamilton, Ont., Canada (1986).

13. ASTM C 150 - 89, "Standard Specification for Portland Cement," 1991 Annual Book of ASTM Standards Section 4 Construction, Vol. 04.02, Concrete and Aggregates, American Association for Testing and Materials, Philadelphia, 1991, pp. 92-96.

14. W. de Laguna, "Radioactive Waste Disposal by Hydraulic Fracturing," Ind. Water Eng. 7, 32-132 (October 1970).

15. T. G. Clendenning, A. E. Dalrymple, and T. W. Klym, "Current Technology in the Utilization and Disposal of Coal Ash," Eng. Con. '75 (1975).

16. E. E. Berry and V. M. Malhotra, "Fly Ash for Use in Concrete - A Critical Review," J. Am. Concr. Inst. 77 (8), 59-73 (1980).

17. R. O. Lane and J. F. Best, "Properties and Use of Fly Ash in Portland Cement Concrete," Concr. Int. 4 (7) 81-92 (1982).

18. R. E. Davis, R. W. Carlson, J. W. Kelley, H. E. Davis, "Properties of Cement and Concrete Containing Fly Ash," ACI J, Proc. 33 (5), 577-612 (1937).

19. E. W. McDaniel, M. T. Morgan, J. G. Moore, H. E. Devaney, and L. R. Dole, Strontium Leachability of Hydrofracture Grouts for Sludge-Slurries, ORNL/TM-8198, Oak Ridge Natl. Lab., March 1982. 
20. J. G. Moore, H. W. Godbee, A. H. Kibbey, and D. S. Joy, Development of Cementitious Grouts for the Incorporation of Radioactive Wastes. Part 1: Leach Studies, ORNL-4962, Oak Ridge Natl. Lab., August 1975.

21. J. G. Moore, Development of Cementitious Grouts for the Incorporation of Radioactive Wastes. Part 2: Continuation of Cesium and Strontium Leach Studies, ORNL-5142, Oak Ridge Natl. Lab., September 1976.

22. A. Atkinson, K. Nelson, and T. M. Valentine, "Leach Test Characterization of Cement-Based Nuclear Waste Forms," Nucl. and Chem. Waste Manage. (6), 242-253 (1986).

23. ASTM C 618 - 91, "Standard Specification for Fly Ash and Raw or Calcined Natural Pozzolan for Use as a Mineral Admixture in Portland Cement Concrete," 1991 Annual Book of ASTM Standards, Sect. 4: Construction, Vol. 04.02, Concrete and Aggregates, American Association for Testing and Materials, Philadelphia, 1991, pp. 303-305.

24. T. M. Gilliam and J. A. Loflin, Leachability Studies of Hydrofracture Grouts, ORNL/TM-9879, Oak Ridge Natl. Lab., November 1986.

25. T. M. Gilliam, "Leach Testing of Hydrofracture Grouts Containing Hazardous Waste," J. Underground Inject. Pract. Coun. 1, 192-212 (1986).

26. R. D. Spence, personal communication from T. L. Sams et al., ORNL, 1987.

27. T. Tamura, "Cesium Sorption Reactions as Indicator of Clay Mineral Structures," Clays Clay Minerals, Proc. Natl. Conf. Clays Clay Minerals 10, 389-398 (1961).

28. T. Tamura, "Cesium Sorption Reactions as Indicator of Clay Mineral Structures," Intern. Clay Conf., Proc. Conf. Stockholm 1, 229-237 (1963).

29. T. Tamura and D. G. Jacobs, "Structural Implications in Cesium Sorption," Health Physics 2, 391-398 (1960). 
30. R. W. Nurse, "Slag Cements," The Chemistry of Cements (H. F. W. Taylor, ed.), Vol. 2, Academic Press, New York, 1984, pp. 37-68.

31. J. Daube and R. Bakker, "Portland Blast Furnace Slag Cement: A Review," Blended Cements, G. Frohnnsdorff, ed., ASTM STP 897, ASTM, Philadelphia, 1986, pp. 5-14.

32. G. Frigione, "Manufacture and Characteristics of Portland Blast-Furnace Slag Cements," Blended Cements, Geoffrey Frohnnsdorf, ed., ASTM STP 897, ASTM, Philadelphia, 1986, pp. 15-28.

33. V. S. Dubovoy, S. H. Gebler, P. Klieger, and D. A. Whiting, "Effects of Ground Granulated BlastFurnace Slags on Some Properties of Pastes, Mortars, and Concretes," Blended Cements, Geoffrey Frohnnsdorff, ed., ASTM STP 897, ASTM, Philadelphia, 1986, pp. 29-48.

34. R. H. Mills, "Chemical Shrinkage and Differential Sorptions in Mixtures of Portland Cement and Blast-Furnace Slag," Blended Cements, Geoffrey Frohnnsdorff, ed., ASTM STP 897, ASTM, Philadelphia, 1986, pp. 49-61.

35. A. M. Neville, Properties of Concrete, $3^{\text {rd }}$ ed., Edward Arnold, Glasgow, 1970.

36. J. D. Palmer and D. L. G. Smith, The Incorporation of Low- and Medium-Level Radioactive Wastes (Solids and Liquids) in Cement, EUR-10561-EN, Commission of the European Communities, Luxembourg, 1986.

37. O. Brown, D. J. Lee, M. S. T. Price, and D. L. G. Smith, "Cement Based Processes for the Immobilization of Intermediate-Level Waste," Radioactive Waste Management, British Nuclear Society, London, 1985.

38. F. P. Glasser and C. McCulloch, Characterization of Radioactive Waste Forms, Progress Report for 1986, EUR-11354, Commission of the European Communities, Luxembourg, 1986.

39. M. J. Angus and F. P. Glasser, "The Chemical Environment in Cement Matrixes," Mater. Res. Soc. Symp. Proc. 50, 547-556 (1986). 
40. R. D. Spence, W. D. Bostick, E. W. McDaniel, T. M. Gilliam, J. L. Shoemaker, O. K. Tallent, I. L. Morgan, B. S. Evans-Brown, K. E. Dodson, "Immobilization of Technetium in Blast Furnace Slag

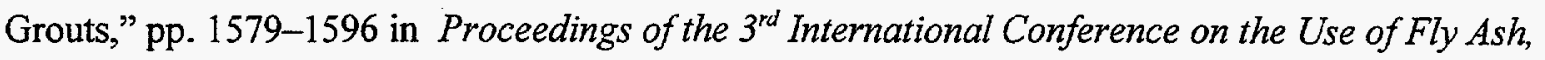
Silica Fume, Slag \& Natural Pozzolans in Concrete, Trondheim, Norway, June 19-24, 1989, Vol. 2 , 1989.

41. T. M. Gilliam, R. D. Spence, W. D. Bostick, and J. L. Shoemaker, "Solidification/Stabilization of Technetium in Cement-Based Grouts," J. Hazardous Mater. 24, pp. 189-197, 1990.

42. R. D. Spence, T. M. Gilliam, and A. Bleier, "Cementitious Stabilization of Chromium, Arsenic, and Selenium in a Cooling Tower Sludge," Paper AM95-15, in Proceedings of the 88th Annual Meeting of the Air \& Waste Management Association, San Antonio, Texas, June 18-23, 1995, Vol. 15, Hazardous, Radioactive, and Mixed Waste, 1995.

43. S. B. Clark and E. L. Wilhite, "Low-Level Liquid Waste Disposal at the Savannah River Site: A Large-Scale Demonstration of Saltstone," WSRC-MS-90-210, DE92 009907, Westinghouse Savannah River Co., Savannah River Laboratory, Aiken, S.C., pp. 603-609 in Proceedings of Waste Management '91, Tucson, Ariz., February 24-28, 1991, 1991.

44. C. A. Langton, M. D. Dukes, and R. V. Simmons, "Cement-Based Waste Forms for Disposal of Savannah River Plant Low-Level Radioactive Salt Waste," DP-MS-83-71, CONF-831174-61, DE84 005197, Savannah River Laboratory, Aiken, S.C., paper presented at the Materials Research Society Annual Meeting, Boston, Mass., November 14-17, 1983; Proceedings published in Scientific Basis for Nuclear Waste Management VII, 1984, pp. 575-582.

45. C. A. Langton, "Solidification of Low-Level Radioactive Waste at the Savannah River Site," WSRC-RP-89-288, DE89 013770, Westinghouse Savannah River Company, Savannah River Laboratory, Aiken, S.C., presented at NIST and NRC Workshop Cement Solidification of Low Level Radioactive Waste, Gaithersburg, Md., May 31-June 12; Proceedings published in NUREG/CP-0103, 1989, pp. 37-40. 
46. C. A. Langton and P. B. Wong "Properties of Slag Concrete for Low-Level Waste Containment," WSRC-MS-91-073, DE92 013194, Westinghouse Savannah River Company, Aiken, S.C., presented at American Concrete Institute Spring Meeting, March 17-21, 1991.

47. D. W. Pepper, Transport of Nitrate from a Large Cement-Based Wasteform, DPST-85-963, DE88 004271, Savannah River Laboratory, Aiken, S.C., 1986.

48. H. C. Wolf, Large-Scale Demonstration of Disposal of Decontaminated Salt as Saltstone Part I: Construction, Loading, and Capping of Lysimeters, DPST-84-497, Savannah River Laboratory, Aiken, S.C., June 1984.

49. S. B. Clark and E. L. Wilhite, E. L. "Low-Level Liquid Waste Disposal at the Savannah River Site: A Large Scale Demonstration of Saltstone," WSRC-MS-90-210, DE92 009907, Westinghouse Savannah River Co., Savannah River Laboratory, Aiken, S.C., Proceedings of Waste Management ‘91, Tucson, Ariz., February 24-28, 1991, pp. 603-609.

50. ASTM C 989 - 89, "Standard Specification for Ground Granulated Blast-Furnace Slag for Use in Concrete and Mortars," 1991 Annual Book of ASTM Standards, Sect. 4: Construction, Vol. 04.02, Concrete and Aggregates, American Association for Testing and Materials, Philadelphia, 1991, pp. $492-496$.

51. ASTM C 204 - 91a, "Standard Specification for Fineness of Portland Cement by Air Permeability Apparatus," 1991 Annual Book of ASTM Standards, Sect. 4: Construction, Vol. 04.01, Cement; Lime; Gypsum, American Association for Testing and Materials, Philadelphia, 1991, pp. 155-161.

52. R. D. Spence, personal communication from T. L. Sams, O. K. Tallent, and E. W. McDaniel, ORNL, 1987.

53. T. M. Gilliam, E. W. McDaniel, L. R. Dole, H. A. Friedman, J. A. Loflin, A. J. Mattus, I. L. Morgan, O. K. Tallent, and G. A. West, Summary Report on the Development of a Cement-Based Formula to Immobilize Hanford Facility Waste, ORNL/TM-10141, Oak Ridge Natl. Lab., September 1987. 
54. R. D. Spence, personal communication from E. W. McDaniel, T. M. Gilliam, and L. R. Dole, ORNL, April 15, 1984.

55. D. K. Smith, Cementing, Monograph, Vol. 4, SPE Henry L. Doherty Series, Society of Petroleum Engineers, Inc., New York, 1990.

56. D. K. Smith, "Physical Properties of Gel Cements," Pet. Eng., B7-B12 (April 1951).

57. R. E. Grim, Applied Clay Mineralogy, McGraw-Hill, New York, 1962.

58. Technical Bulletin Data No. 201, American Callard Co., Chicago, 1945.

59. W. de Laguna, T. Tamura, H. O. Weeren, E. G. Struxness, and W. D. McClain, Engineering Development of Hydraulic Fracturing as a Method for Permanent Disposal of Radioactive Wastes, ORNL-4259, Oak Ridge Natl. Lab, August 1968.

60. API Specification for Oil-Well Drilling-Fluid Materials, API Spec $12 \mathrm{~A}, 9^{\text {th }}$ ed., American Petroleum Institute, Dallas, March 1983.

61. "Specifications for Materials and Testing Oil-Well Cements," API Specification 10, 2" ed., American Petroleum Institute, Dallas, 1984.

62. P. K.. Mehta and N. Pitt, "Energy and Industrial Materials from Crop Residues," Resour. Recovery Conserv. 2, 23-38 (1976). 


\begin{tabular}{|c|c|c|c|}
\hline \multirow[b]{2}{*}{ Ions } & \multicolumn{3}{|c|}{$\mathrm{mg} / \mathrm{kg}$} \\
\hline & TH4 sludge sample & $\begin{array}{l}\text { FY96 GAAT surrogate (wt'd } \\
\text { avg + max bad actors) }\end{array}$ & FY98 TH4 surrogate sludge \\
\hline $\mathrm{Ag}$ & 13.4 & & \\
\hline As & $<1.67$ & & \\
\hline $\mathrm{Hg}$ & $<0.00668$ & 208 & 146 \\
\hline $\mathrm{Pb}$ & $<6.03$ & 3210 & 2256 \\
\hline $\mathrm{Al}$ & 2630 & 11424 & 1848 \\
\hline B & 37.6 & & \\
\hline $\mathrm{Ba}$ & 9.54 & & \\
\hline $\mathrm{Be}$ & 68.1 & & \\
\hline $\mathrm{Ca}$ & 1250 & 8634 & 879 \\
\hline $\mathrm{Cd}$ & $<5.72$ & & \\
\hline Co & 9.62 & & \\
\hline $\mathrm{Cu}$ & 31 & & \\
\hline $\mathrm{Fe}$ & 3300 & 6512 & 2319 \\
\hline $\mathrm{K}$ & 762 & 3002 & 536 \\
\hline $\mathrm{Mg}$ & $<1.68$ & 2082 & 224 \\
\hline $\mathrm{Mn}$ & 28.7 & & \\
\hline $\mathrm{Na}$ & 29900 & 35001 & 45742 \\
\hline $\mathrm{Ni}$ & 21.8 & & \\
\hline $\mathrm{Se}$ & $<1.67$ & & \\
\hline $\mathrm{Sb}$ & $<27.2$ & & \\
\hline $\mathrm{Si}$ & 13900 & & 9769 \\
\hline $\mathrm{Sr}$ & 8.55 & & \\
\hline Th & 75200 & 21960 & 52852 \\
\hline $\mathrm{Tl}$ & $<1.67$ & & \\
\hline $\mathrm{U}$ & 36900 & 36578 & 25934 \\
\hline V & $<0.61$ & & \\
\hline $\mathrm{Zn}$ & $<13.4$ & & \\
\hline $\mathrm{Zr}$ & 3770 & & \\
\hline $\mathrm{Cr}$ & 208 & 1258 & 884 \\
\hline Chloride & 723 & 2535 & 508 \\
\hline Fluoride & 1010 & 5482 & 710 \\
\hline Nitrate & 13600 & 42528 & 70003 \\
\hline Nitrite & 281 & & 197 \\
\hline Phosphate & 34400 & 5839 & 24177 \\
\hline Sulfate & 10900 & 9869 & 7661 \\
\hline $\begin{array}{c}\text { TIC } \\
\text { (carbonate) }\end{array}$ & $<1000$ & $\begin{array}{c}4494 \\
(22454)\end{array}$ & 6853 \\
\hline $\begin{array}{l}\text { TOC } \\
\text { (TBP) }\end{array}$ & 8730 & $\begin{array}{c}6182 \\
(11423)\end{array}$ & 6136 \\
\hline Ca oxalate & & 100 & 70 \\
\hline Water, wt $\%$ & $66.20 \%$ & $73.9 \%$ & $66.20 \%$ \\
\hline $\mathrm{pH}$ & 10 & & \\
\hline
\end{tabular}


Table 2. Composition of the surrogate

\section{TH4 sludge}

\begin{tabular}{|c|c|c|}
\hline \multicolumn{2}{|c|}{ Compound } & Concentration $(\mathrm{mg} / \mathrm{kg})$ \\
\hline \multicolumn{2}{|l|}{$\overline{\mathrm{HgCl}_{2}}$} & 197 \\
\hline \multicolumn{2}{|l|}{$\mathrm{PbO}$} & 2430 \\
\hline \multicolumn{2}{|l|}{$\mathrm{Al}(\mathrm{OH})_{3}$} & 5344 \\
\hline \multicolumn{2}{|l|}{$\mathrm{Ca}(\mathrm{OH})_{2}$} & 1588 \\
\hline \multicolumn{2}{|l|}{$\mathrm{Fe}_{2} \mathrm{O}_{3}$} & 3316 \\
\hline \multicolumn{2}{|l|}{$\mathrm{K}_{2} \mathrm{CO}_{3}$} & 1088 \\
\hline \multicolumn{2}{|l|}{$\mathrm{Mg}(\mathrm{OH})_{2}$} & 537 \\
\hline \multicolumn{2}{|l|}{$\mathrm{SiO}_{2}$} & 20899 \\
\hline \multicolumn{2}{|c|}{$\mathrm{Th}\left(\mathrm{NO}_{3}\right)_{4} \cdot 4 \mathrm{H}_{2} \mathrm{O}$} & 125758 \\
\hline \multicolumn{2}{|c|}{$\mathrm{UO}_{2}\left(\mathrm{NO}_{3}\right)_{2} \cdot 6 \mathrm{H}_{2} \mathrm{O}$} & 54707 \\
\hline \multicolumn{2}{|c|}{$\mathrm{Na}_{2} \mathrm{Cr}_{2} \mathrm{O} 7 \cdot 2 \mathrm{H}_{2} \mathrm{O}$} & 2533 \\
\hline \multicolumn{2}{|l|}{$\mathrm{NaCl}$} & 753 \\
\hline \multicolumn{2}{|l|}{$\mathrm{NaF}$} & 1569 \\
\hline \multicolumn{2}{|l|}{$\mathrm{NaNO}_{2}$} & 296 \\
\hline \multicolumn{2}{|l|}{$\mathrm{Na}_{3} \mathrm{PO}_{4}$} & 34756 \\
\hline \multicolumn{2}{|l|}{$\mathrm{Na}_{2} \mathrm{SO}_{4}$} & 11328 \\
\hline \multicolumn{2}{|l|}{$\mathrm{Na}_{2} \mathrm{CO}_{3}$} & 59493 \\
\hline Total salts & $\begin{array}{l}\mathrm{mg} / \mathrm{kg} \\
\mathrm{wt} \%\end{array}$ & $\begin{array}{r}326592 \\
32.66 \%\end{array}$ \\
\hline TBP & $\begin{array}{l}\mathrm{mg} / \mathrm{kg} \\
\mathrm{wt} \%\end{array}$ & $\begin{array}{r}11337 \\
1.13 \%\end{array}$ \\
\hline $\mathrm{CaC}_{2} \mathrm{O}_{4} \cdot \mathrm{H}_{2} \mathrm{O}$ & $\begin{array}{l}\mathrm{mg} / \mathrm{kg} \\
\text { wt } \%\end{array}$ & $\begin{array}{l}70 \\
0.01 \%\end{array}$ \\
\hline Water & $w t \%$ & $66.20 \%$ \\
\hline \multicolumn{2}{|c|}{ Mass Balance wt $\%$} & $100 \%$ \\
\hline
\end{tabular}




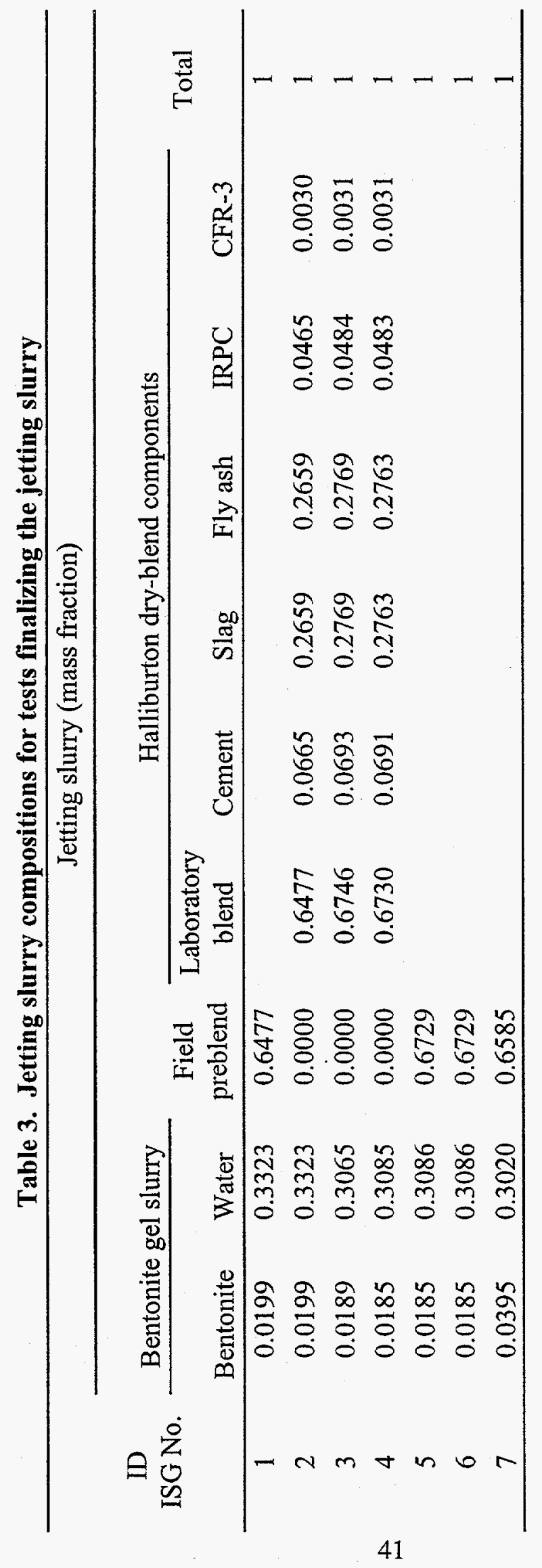


Table 4. Jetting slurry density for the tests finalizing the jetting slurry

\begin{tabular}{ccccc}
\hline \multirow{2}{*}{ ID } & \multicolumn{4}{c}{ Jetting slurry density } \\
\cline { 2 - 5 } ISG No. & \multicolumn{3}{c}{ Mud balance } & \multicolumn{2}{c}{ Graduated cylinder } \\
\cline { 2 - 5 } & $(\mathrm{lb} / \mathrm{gal})$ & $\mathrm{g} / \mathrm{mL})$ & $(\mathrm{g} / \mathrm{mL})$ & $(\mathrm{b} / \mathrm{gal})$ \\
\hline 1 & 13.5 & 1.62 & 1.68 & 14.0 \\
2 & 13.6 & 1.63 & 1.66 & 13.9 \\
3 & 14.3 & 1.72 & 1.72 & 14.3 \\
4 & 14.4 & 1.73 & 1.73 & 14.4 \\
5 & & & 1.74 & 14.5 \\
6 & & & 1.74 & 14.5 \\
7 & & & 1.76 & 14.7 \\
\hline
\end{tabular}



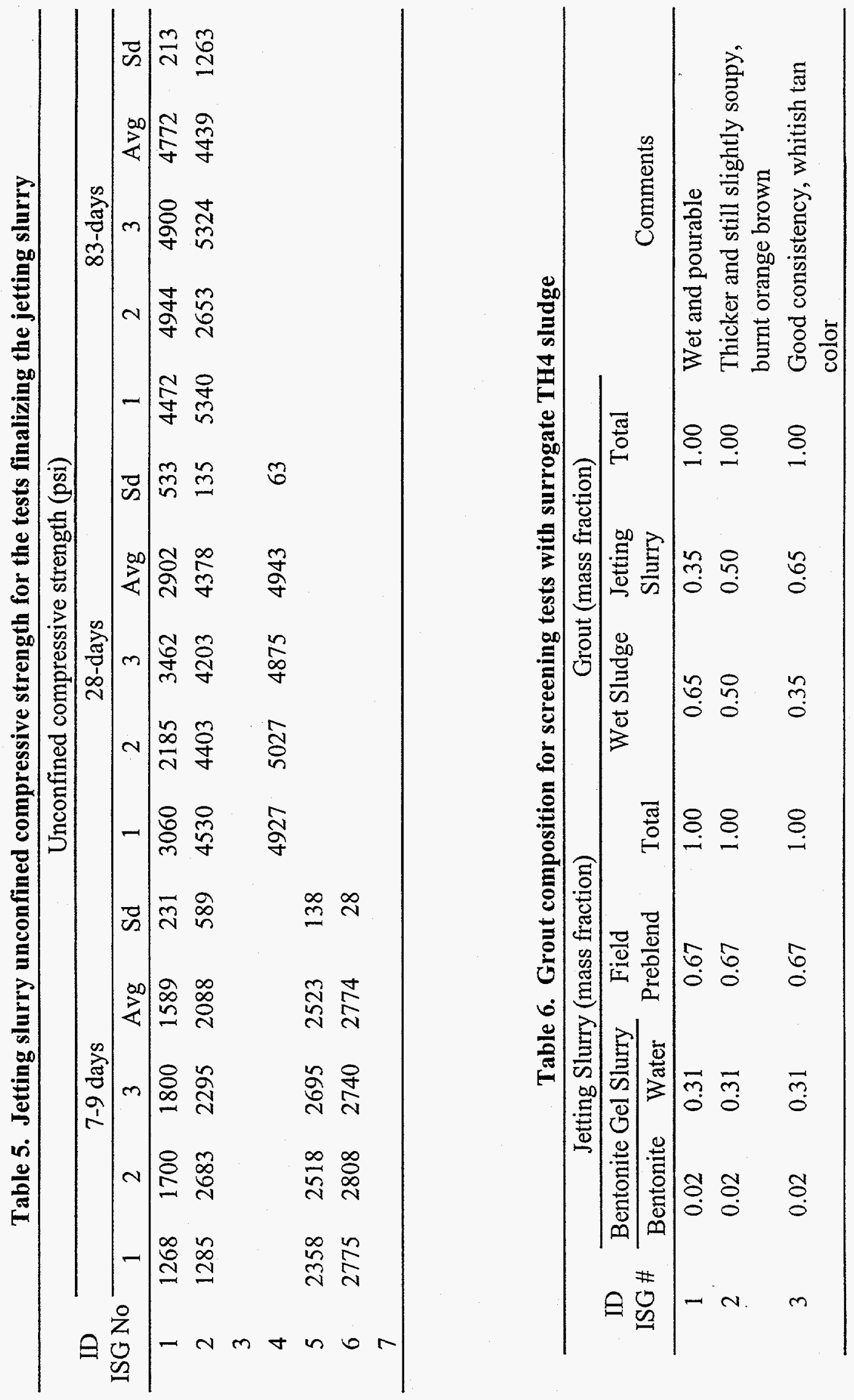
Table 7. Grout density and grout:sludge volume ratio for screening tests with surrogate TH4 sludge

\begin{tabular}{ccc}
\hline ID & Density $(\mathrm{g} / \mathrm{mL})$ & $\begin{array}{c}\text { Grout-to-sludge + sup } \\
\text { vol ratio }\end{array}$ \\
\hline ISG No. & 1.22 & \\
Surrogate sludge & 1.36 & 1.38 \\
1 & 1.40 & 1.75 \\
2 & 1.50 & 2.32 \\
\hline
\end{tabular}

Table 8. Bleed water for screening tests with surrogate TH4 sludge

\begin{tabular}{ccccc}
\hline D & \multicolumn{4}{c}{ Bleed water (mass fraction) } \\
\cline { 2 - 5 } ISG No. & $1 \mathrm{~d}$ & $2 \mathrm{~d}$ & $5 \mathrm{~d}$ & $7 \mathrm{~d}$ \\
1 & 0.0120 & 0.0120 & & 0.0120 \\
2 & 0.0000 & 0.0000 & & 0.0000 \\
3 & & & 0.0000 & 0.0000 \\
\hline
\end{tabular}

Table 9. Penetration resistance for screening tests with surrogate TH4 sludge

\begin{tabular}{crrrrrr}
\hline ID & \multicolumn{7}{c}{ Penetration resistance (psi) } \\
\cline { 2 - 7 } ISG No. & $1 \mathrm{~d}$ & $2 \mathrm{~d}$ & $5 \mathrm{~d}$ & $7 \mathrm{~d}$ & $14 \mathrm{~d}$ & $85 \mathrm{~d}$ \\
\hline 1 & 0 & 0 & & 0 & 0 & \\
2 & 0 & 0 & & 0 & & 5160 \\
3 & & & 4000 & 5600 & & \\
\hline
\end{tabular}

Table 10. Unconfined compressive strength for screening tests with surrogate TH4 sludge

\begin{tabular}{|c|c|c|c|c|c|c|c|c|c|c|}
\hline \multirow{3}{*}{$\begin{array}{c}\text { ID } \\
\text { ISG No. }\end{array}$} & \multicolumn{10}{|c|}{ Unconfined compressive strength (psi) } \\
\hline & \multicolumn{5}{|c|}{$7 \mathrm{~d}$} & \multicolumn{5}{|c|}{$40-42 \mathrm{~d}$} \\
\hline & 1 & 2 & 3 & avg & sd & 1 & 2 & 3 & avg & sd \\
\hline \multicolumn{11}{|l|}{1} \\
\hline 2 & & & & & & 172 & 242 & 212 & 209 & 29 \\
\hline 3 & 797 & 798 & 878 & 824 & 38 & 1652 & 1806 & 1906 & 1788 & 105 \\
\hline
\end{tabular}

Table 11. TCLP extract concentrations for screening tests with surrogate TH4 sludge

\begin{tabular}{cccc}
\hline ID & \multicolumn{3}{c}{ TCLP extract concentration (mg/L) } \\
\cline { 2 - 4 } ISG No. & $\mathrm{Cr}$ & $\mathrm{Pb}$ & \multicolumn{1}{c}{$\mathrm{Hg}$} \\
\hline Surrogate sludge & 104.27 & 0.51 & 15.64656 \\
1 & 1.794 & 0.066 & 0.000512 \\
2 & 0.082 & 0.029 & 0.00078 \\
3 & 0.14 & $<0.014$ & 0.000045 \\
UTS & 0.86 & 0.37 & 0.025 \\
\hline
\end{tabular}




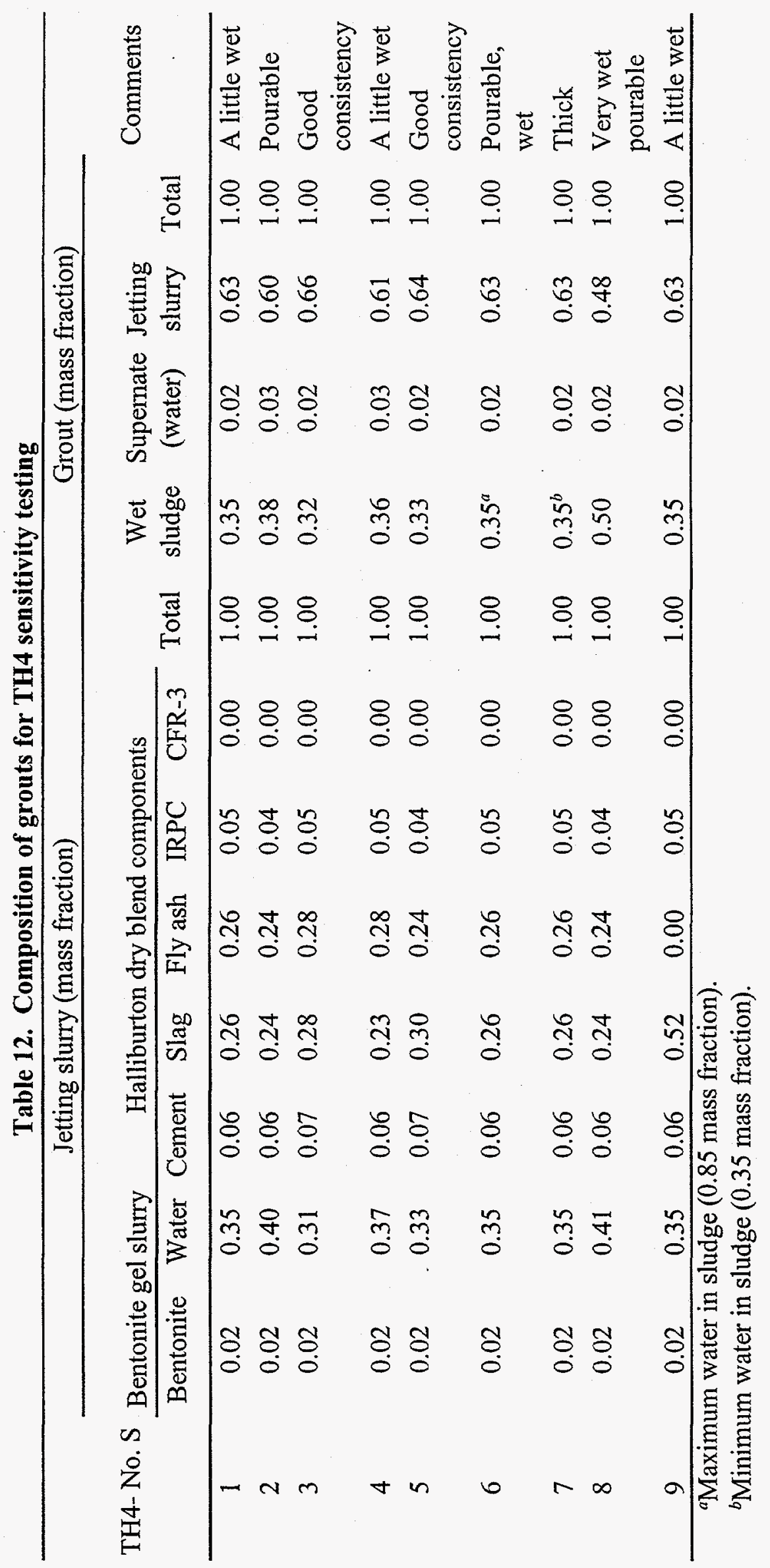


Table 13. Density and volume ratio for TH4 sensitivity testing

\begin{tabular}{ccc}
\hline TH4-No.S & Density $(\mathrm{g} / \mathrm{mL})$ & Grout to sludge + sup vol ratio \\
\hline 1 & 1.43 & 2.32 \\
2 & 1.36 & 2.26 \\
3 & 1.47 & 2.47 \\
4 & 1.37 & 2.33 \\
5 & 1.46 & 2.39 \\
6 & 1.27 & 2.60 \\
7 & 1.62 & 2.06 \\
8 & 1.33 & 1.78 \\
9 & 1.65 & 2.03 \\
\hline
\end{tabular}

Table 14. Bleed water for TH4 sensitivity testing

\begin{tabular}{cccc}
\hline & \multicolumn{3}{c}{ Bleed water (mass fraction) } \\
\cline { 2 - 4 } TH4- No.S & $2 \mathrm{~d}$ & $7 \mathrm{~d}$ & $28-31 \mathrm{~d}$ \\
\hline 1 & 0.0000 & 0.0000 & 0.0000 \\
2 & 0.0080 & 0.0060 & 0.0000 \\
3 & 0.0000 & 0.0000 & 0.0000 \\
4 & 0.0080 & 0.0000 & 0.0000 \\
5 & 0.0000 & 0.0000 & 0.0000 \\
6 & 0.0020 & 0.0000 & 0.0000 \\
7 & 0.0000 & 0.0000 & 0.0000 \\
8 & 0.0120 & 0.0080 & 0.0020 \\
9 & 0.0000 & 0.0000 & 0.0000 \\
\hline
\end{tabular}


Table 15. Penetration resistance for TH4 sensitivity testing

\begin{tabular}{ccrrr}
\hline & \multicolumn{4}{c}{ Penetration resistance (psi) } \\
\cline { 2 - 5 } TH4-No. S & $2 \mathrm{~d}$ & \multicolumn{1}{c}{$\mathrm{d}$} & $28-31 \mathrm{~d}$ & $72 \mathrm{~d}$ \\
\hline 1 & 0 & 800 & 4400 & \\
2 & 0 & 0 & 0 & 880 \\
3 & 0 & 1840 & 5600 & 320 \\
4 & 0 & 0 & 160 & \\
5 & 0 & 1760 & 5200 & 0 \\
6 & 0 & 600 & 3200 & 0 \\
7 & 0 & 0 & 0 & \\
8 & 0 & 0 & 0 & \\
9 & 0 & 4400 & 7200 & \\
\hline
\end{tabular}

Table 16. Unconfined compressive strength for TH4 sensitivity testing

\begin{tabular}{crrrrr}
\hline & \multicolumn{5}{c}{$28-31$ day unconfined compressive strength (psi) } \\
\cline { 2 - 6 } TH4-No. S & 1 & 2 & 3 & Avg & Sd \\
\hline 1 & 529 & 593 & 621 & 581 & 39 \\
2 & & & & & \\
3 & 860 & 820 & 843 & 841 & 17 \\
4 & & & & & \\
5 & 788 & 851 & 760 & 800 & 38 \\
6 & 373 & 341 & 352 & 355 & 13 \\
7 & & & & & \\
8 & & & & & \\
9 & 1421 & 1404 & 1286 & 1370 & \\
\hline
\end{tabular}


Table 17. TCLP extract concentrations for TH4 sensitivity testing

\begin{tabular}{cccl}
\hline & \multicolumn{3}{c}{ TCLP extract concentration $(\mathrm{mg} / \mathrm{L})$} \\
\cline { 2 - 4 } TH4-No. S & $\mathrm{Cr}$ & $\mathrm{Pb}$ & \multicolumn{1}{c}{$\mathrm{Hg}$} \\
\hline 1 & $<0.010$ & $<0.014$ & 0.00033 \\
2 & 0.071 & 0.082 & 0.0065 \\
3 & $<0.010$ & $<0.014$ & 0.00092 \\
4 & 0.02 & $<0.014$ & 0.00026 \\
5 & $<0.010$ & $<0.014$ & 0.0001 \\
6 & $<0.010$ & $<0.014$ & 0.00011 \\
7 & 0.02 & 0.04 & 0.0008 \\
8 & 0.163 & 0.03 & 0.00074 \\
9 & $<0.010$ & $<0.014$ & 0.00019 \\
& & UTS limits & \\
& 0.86 & 0.37 & 0.025 \\
\hline
\end{tabular}

Table 18. ${ }^{85} \mathrm{Sr}$ and ${ }^{137} \mathrm{Cs}$ leachability indices for TH4 sensitivity testing

\begin{tabular}{ccc}
\hline & \multicolumn{3}{c}{ Leachability index } \\
\cline { 2 - 3 } TH4-No. S & ${ }^{85} \mathrm{Sr}$ & ${ }^{137} \mathrm{Cs}$ \\
\hline & 9.1 & 10.8 \\
2 & 9.2 & 11.0 \\
3 & 9.2 & 10.9 \\
4 & 8.9 & 10.4 \\
5 & 9.1 & 11.0 \\
6 & 8.7 & 10.1 \\
7 & 9.3 & 11.0 \\
8 & 8.7 & 10.5 \\
& 9.5 & 10.0 \\
9 & $a$ & $a$ \\
& 9.3 & 11.3 \\
& 9.1 & 11.1 \\
\hline
\end{tabular}

${ }^{9}$ Not applicable. Sample too soft to record and measure value. 
Table 19. Total concentrations measured in the slag samples $(\mathrm{mg} / \mathrm{kg})$

\begin{tabular}{|c|c|c|c|c|c|c|c|}
\hline \multirow[b]{2}{*}{ Analyte } & \multicolumn{2}{|c|}{ Halliburton slag } & \multicolumn{2}{|c|}{ Holnam slag } & \multicolumn{3}{|c|}{ NIST standard glass ${ }^{a}$} \\
\hline & 1 & 2 & 1 & 2 & 1 & 2 & $\begin{array}{c}\text { Actual } \\
\text { from } \\
\text { NIST }\end{array}$ \\
\hline Silver & $<10$ & $<10$ & $<9$ & $<10$ & 115 & 156 & 254 \\
\hline Aluminum & 48,174 & 36,407 & 37,180 & 45,712 & 10,114 & 10,106 & 10,580 \\
\hline Arsenic & $<40$ & $<40$ & $<37$ & $<39$ & 335 & 352 & \\
\hline Boron & 681,694 & 641,224 & 625,080 & 676,412 & 630,414 & 595,713 & 351 \\
\hline Barium & 876 & 728 & 317 & 374 & 392 & 398 & \\
\hline Beryllium & 5 & 4 & 11 & 13 & 426 & 433 & \\
\hline Calcium & 221,852 & 180,762 & 239,970 & 259,390 & 74,999 & 71,472 & 85,700 \\
\hline Cadmium & $<4$ & $<4$ & $<4$ & $<4$ & 259 & 268 & \\
\hline Chromium & 28 & 27 & 62 & 70 & 404 & 410 & \\
\hline Copper & $<16$ & 26 & $<15$ & $<16$ & 424 & 443 & 444 \\
\hline Iron & 7,492 & 7,134 & 3,933 & 4,722 & 473 & 566 & 458 \\
\hline Potassium & 2,566 & 2,562 & 3,206 & 3,599 & 466 & 950 & 461 \\
\hline Magnesium & 37,404 & 27,591 & 56,034 & 67,373 & 749 & 852 & \\
\hline Manganese & 3,049 & 2,992 & 5,464 & 5,991 & 425 & 430 & 485 \\
\hline Sodium & 4,233 & 5,957 & 5,185 & 2,246 & 91,447 & 90,499 & 103,800 \\
\hline Nickel & $<16$ & $<16$ & $<15$ & $<16$ & 424 & 444 & 459 \\
\hline Lead & $<28$ & $<28$ & $<26$ & $<27$ & 392 & 409 & 426 \\
\hline Selenium & $<40$ & $<40$ & $<37$ & $<39$ & 48 & 91 & \\
\hline Antimony & $<40$ & $<40$ & $<37$ & $<39$ & 380 & 393 & \\
\hline Silicon & 229,204 & 268,531 & 234,043 & 272,459 & 314,473 & 288,718 & 336,570 \\
\hline Strontium & 347 & 297 & 244 & 284 & 401 & 413 & 515 \\
\hline Thorium & 1,508 & 1,487 & 1,460 & 1,572 & 675 & $<491$ & 457 \\
\hline Titanium & 3,087 & 3,030 & 9,696 & 11,027 & 391 & 391 & 437 \\
\hline Thallium & $<32$ & $<32$ & $<29$ & $<31$ & 81 & 135 & 62 \\
\hline Uranium & 892 & 865 & 833 & 890 & 1,122 & 1,005 & 462 \\
\hline Vanadium & $<40$ & $<40$ & $<37$ & $<39$ & 434 & 441 & \\
\hline Zinc & 43 & 56 & 44 & 52 & 444 & 453 & 433 \\
\hline Zirconium & $<40$ & $<40$ & 240 & 249 & 466 & 462 & \\
\hline
\end{tabular}

${ }^{a}$ An NIST standard used to check the accuracy of the technique. 
Table 20. Chemical analysis of sludge sample from GAAT TH-4

\begin{tabular}{crcccc}
\hline $\begin{array}{c}\text { Nonradioactive } \\
\text { component }\end{array}$ & $\mu \mathrm{g} / \mathrm{g}$ & $\begin{array}{c}\text { Nonradioactive } \\
\text { component }\end{array}$ & $\mu \mathrm{g} / \mathrm{g}$ & Radionuclide & $\mathrm{Bg} / \mathrm{g}$ \\
\hline $\mathrm{Ag}$ & $1.34 \mathrm{E}+01$ & $\mathrm{Na}$ & $2.99 \mathrm{E}+04$ & $\mathrm{Am}-241$ & $<7.3 \mathrm{E}+01$ \\
$\mathrm{Al}$ & $2.63 \mathrm{E}+03$ & $\mathrm{Ni}$ & $2.18 \mathrm{E}+01$ & $\mathrm{Co}-60$ & $<5.1 \mathrm{E}+01$ \\
$\mathrm{~B}$ & $3.76 \mathrm{E}+01$ & $\mathrm{NO} 2$ & $2.81 \mathrm{E}+02$ & $\mathrm{Cs}-134$ & $<3.7 \mathrm{E}+01$ \\
$\mathrm{Ba}$ & $9.54 \mathrm{E}+00$ & $\mathrm{NO} 3$ & $1.36 \mathrm{E}+04$ & $\mathrm{Cs}-137$ & $5.20 \mathrm{E}+02$ \\
$\mathrm{Be}$ & $6.81 \mathrm{E}+01$ & $\mathrm{P}$ (Microwave) & $3.44 \mathrm{E}+04$ & Eu-152 & $<2.5 \mathrm{E}+02$ \\
$\mathrm{Br}$ & $<4.94 \mathrm{E}+00$ & $\mathrm{P}$ (Fusion) & $4.92 \mathrm{E}+03$ & Eu-154 & $<1.5 \mathrm{E}+02$ \\
$\mathrm{Ca}$ & $1.25 \mathrm{E}+03$ & $\mathrm{~Pb}$ & $<6.03 \mathrm{E}+00$ & Eu-155 & $<8.4 \mathrm{E}+01$ \\
$\mathrm{Cd}$ & $<5.72 \mathrm{E}+00$ & $\mathrm{PO} 4$ & $4.89 \mathrm{E}+03$ & $\mathrm{G}-\mathrm{alpha}$ & $3.30 \mathrm{E}+03$ \\
& & $\mathrm{~S}$ as SO4 & & & \\
$\mathrm{Cl}$ & 108 & (Microwave) & $1.09 \mathrm{E}+04$ & Total-act & $1.10 \mathrm{E}+04$ \\
$\mathrm{Cl}$ (Fusion) & 723 & $\mathrm{~S}$ as SO4 (Fusion) & $9.76 \mathrm{E}+03$ & Total-rad-Sr & $2.40 \mathrm{E}+04$ \\
$\mathrm{Co}$ & $9.62 \mathrm{E}+00$ & $\mathrm{Sb}$ & $<2.72 \mathrm{E}+01$ & & \\
$\mathrm{Cr}$ & $2.08 \mathrm{E}+02$ & $\mathrm{Si}$ (HF) & $1.39 \mathrm{E}+04$ & & \\
$\mathrm{Cu}$ & $3.10 \mathrm{E}+01$ & $\mathrm{SO}$ & $8.64 \mathrm{E}+03$ & Other & \\
$\mathrm{F}$ & $5.79 \mathrm{E}+02$ & $\mathrm{Sr}$ & $8.55 \mathrm{E}+00$ & & \\
$\mathrm{~F}$ (Fusion) & $1.01 \mathrm{E}+03$ & $\mathrm{Th}$ & $7.52 \mathrm{E}+04$ & Density & $1.38 \mathrm{~g} / \mathrm{mL}$ \\
$\mathrm{Fe}$ & $2.06 \mathrm{E}+03$ & $\mathrm{U}$ & $3.69 \mathrm{E}+04$ & Moisture & $66.20 \%$ \\
$\mathrm{~K}$ & $7.62 \mathrm{E}+02$ & $\mathrm{~V}$ & $<6.10 \mathrm{E}+01$ & pH & 10.09 \\
$\mathrm{Li}$ & $<1.53 \mathrm{E}+00$ & $\mathrm{Zn}$ & $<1.34 \mathrm{E}+01$ & TIC & $<0.1 \%$ \\
$\mathrm{Mg}$ & $<1.68 \mathrm{E}+00$ & $\mathrm{Zr}$ & $3.77 \mathrm{E}+03$ & TOC & $0.87 \%$ \\
$\mathrm{Mn}$ & $2.87 \mathrm{E}+01$ & & & Total-carbon & $0.87 \%$ \\
\hline
\end{tabular}


Table 21. Density, penetration resistance, compressive strength, and leachability indices of grout with

TH-4 sludge ( $35 \mathrm{wt} \%$ hot test)

$$
\text { Density" }
$$

$267.1 \mathrm{~g} / 169 \mathrm{~mL}=1.58 \mathrm{~g} / \mathrm{mL}$

\section{$\underline{\text { Penetration resistance }}$}

Test No. 1 Test No. 2 Test No. 3 Average

$4 d$

$\begin{array}{cccc}3 \mathrm{lb} & 2 \mathrm{lb} & 2 \mathrm{lb} & 2 \mathrm{lb} \\ 120 \mathrm{psi} & 80 \mathrm{psi} & 80 \mathrm{psi} & 80 \mathrm{psi}\end{array}$

$7 d$

$\begin{array}{cccc}68 \mathrm{lb} & 66 \mathrm{lb} & 57 \mathrm{lb} & 64 \mathrm{lb} \\ 2720 \mathrm{psi} & 2640 \mathrm{psi} & 2280 \mathrm{psi} & 2560 \mathrm{psi}\end{array}$

\section{Compressive strength}

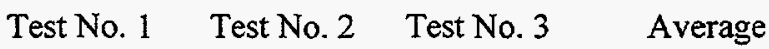

$\begin{array}{ccccc}7 \mathrm{~d} & 889 \mathrm{lb} & 660 \mathrm{lb} & 776 \mathrm{lb} & 775 \mathrm{lb} \\ & 222 \mathrm{psi} & 165 \mathrm{psi} & 194 \mathrm{psi} & 194 \mathrm{psi} \\ & & & & \\ 28 \mathrm{~d} & 5650 \mathrm{lb} & 5250 \mathrm{lb} & 5480 \mathrm{lb} & 5460 \mathrm{lb} \\ & 1413 \mathrm{psi} & 1313 \mathrm{psi} & 1370 \mathrm{psi} & 1365 \mathrm{psi}\end{array}$

\section{Leachability index}

Test No. 1 Test No. 2 Test No. $3 \quad$ Average

$\begin{array}{lllll}{ }^{89 / 90} \mathrm{Sr} & 13.6 & 13.5 & 13.6 & 13.6 \\ { }^{137} \mathrm{Cs} & 10.6 & 10.8 & 10.5 & 10.6\end{array}$

No free water.

${ }^{b} 0.025$ (1/40)-in. ${ }^{2}$ shaft. 
Table 22. TCLP results on the GAAT TH-4 sludge sample and the grout sample with TH-4 sludge

\begin{tabular}{crrr}
\hline & $\begin{array}{c}\text { GAAT TH-4 sludge } \\
\text { sample } \\
\mu \mathrm{g} / \mathrm{mL}\end{array}$ & $\begin{array}{c}\text { Grout with TH-4 } \\
\text { sludge }(35 \mathrm{wt} \%) \\
\mu \mathrm{g} / \mathrm{mL}\end{array}$ & $\begin{array}{c}\text { UTS limits } \\
\mu \mathrm{g} / \mathrm{mL}\end{array}$ \\
\hline & & & \\
$\mathrm{Component}$ & $8.35 \mathrm{E}-03$ & $1.34 \mathrm{E}-01$ & $3.00 \mathrm{E}-01$ \\
$\mathrm{Ag}$ & $<8.35 \mathrm{E}-02$ & $<1.67 \mathrm{E}-02$ & $5.00 \mathrm{E}+00$ \\
$\mathrm{As}$ & $1.34 \mathrm{E}-01$ & $1.14 \mathrm{E}-01$ & $7.60 \mathrm{E}+00$ \\
$\mathrm{Ba}$ & $<1.67 \mathrm{E}-03$ & $<1.67 \mathrm{E}-03$ & $1.40 \mathrm{E}-02$ \\
$\mathrm{Be}$ & $<1.25 \mathrm{E}-01$ & $<1.29 \mathrm{E}-01$ & $1.90 \mathrm{E}-01$ \\
$\mathrm{Cd}$ & $5.85 \mathrm{E}-02$ & $<4.51 \mathrm{E}-02$ & $8.60 \mathrm{E}-01$ \\
$\mathrm{Cr}$ & $<3.34 \mathrm{E}-04$ & $<1.67 \mathrm{E}-02$ & $2.50 \mathrm{E}-02$ \\
$\mathrm{Hg}$ & $4.44 \mathrm{E}-01$ & $<9.02 \mathrm{E}-02$ & $5.00 \mathrm{E}+00$ \\
$\mathrm{Ni}$ & $<1.32 \mathrm{E}-01$ & $<1.67 \mathrm{E}-02$ & $3.70 \mathrm{E}-01$ \\
$\mathrm{~Pb}$ & $<5.95 \mathrm{E}-01$ & $<1.67 \mathrm{E}-02$ & $2.10 \mathrm{E}+00$ \\
$\mathrm{Sb}$ & $<8.35 \mathrm{E}-02$ & $<1.67 \mathrm{E}-02$ & $1.60 \mathrm{E}-01$ \\
$\mathrm{Se}$ & $<8.35 \mathrm{E}-02$ & $<1.40 \mathrm{E}+00$ & $7.80 \mathrm{E}-02$ \\
$\mathrm{Tl}$ & &
\end{tabular}




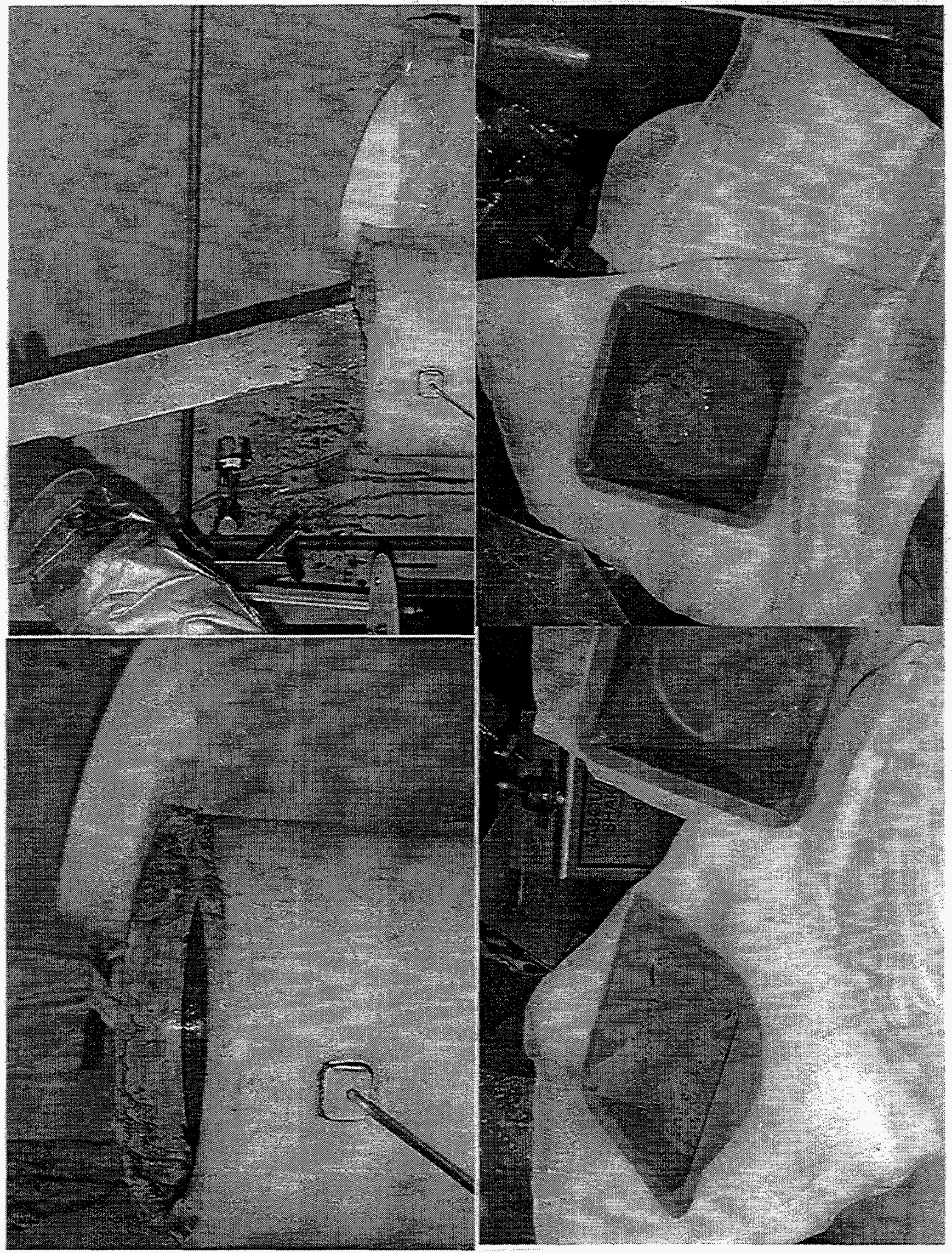

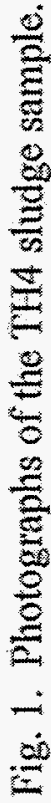




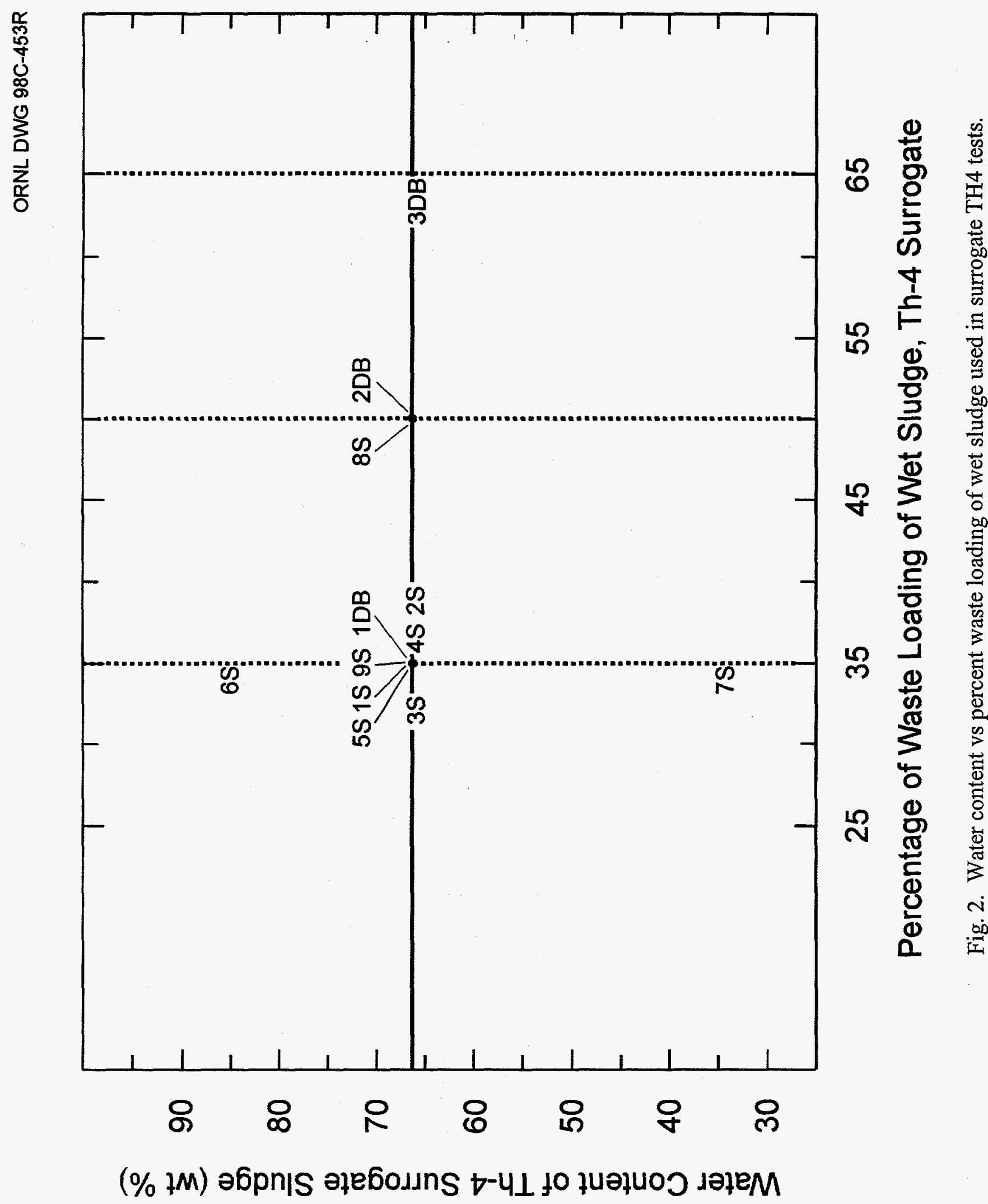




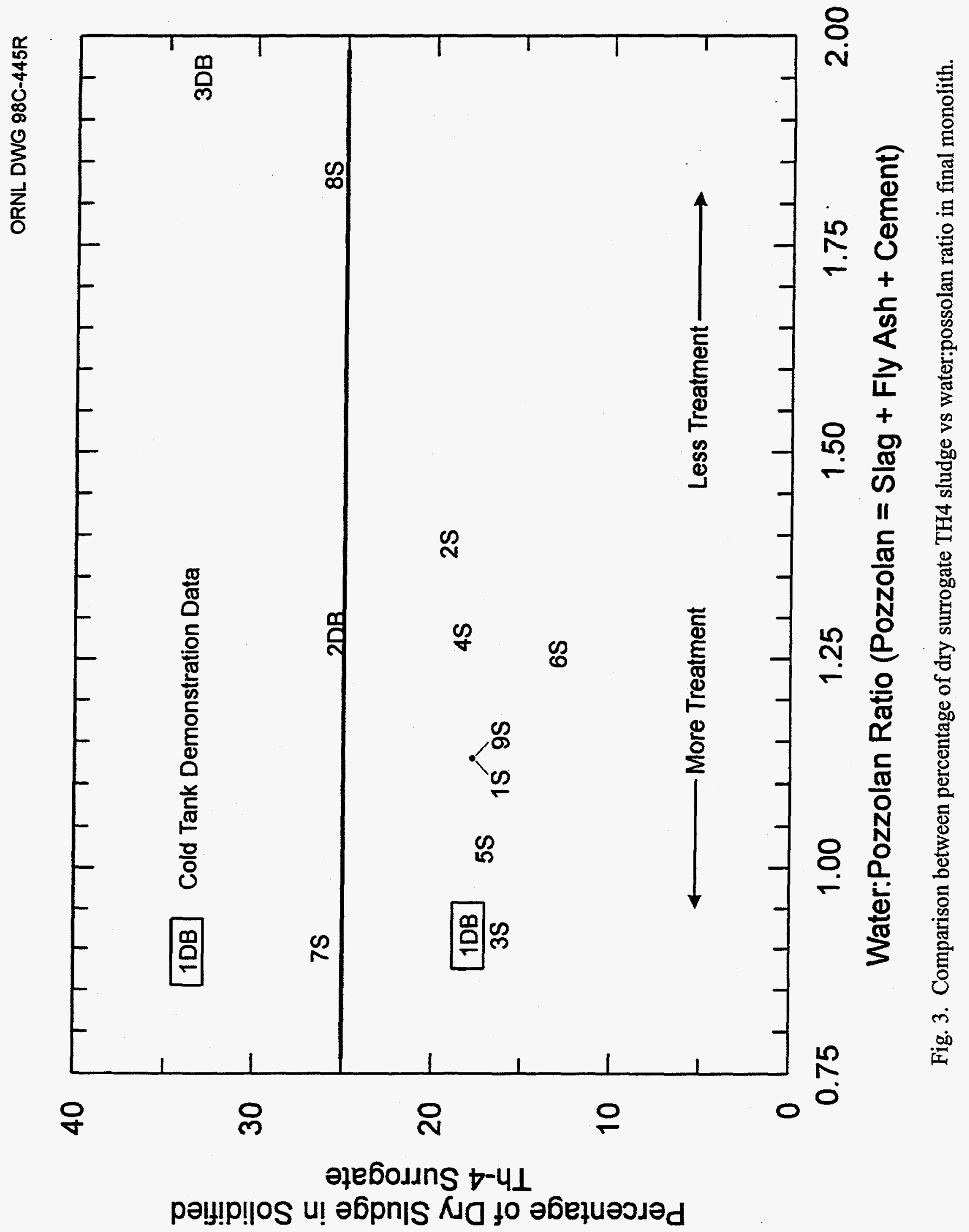




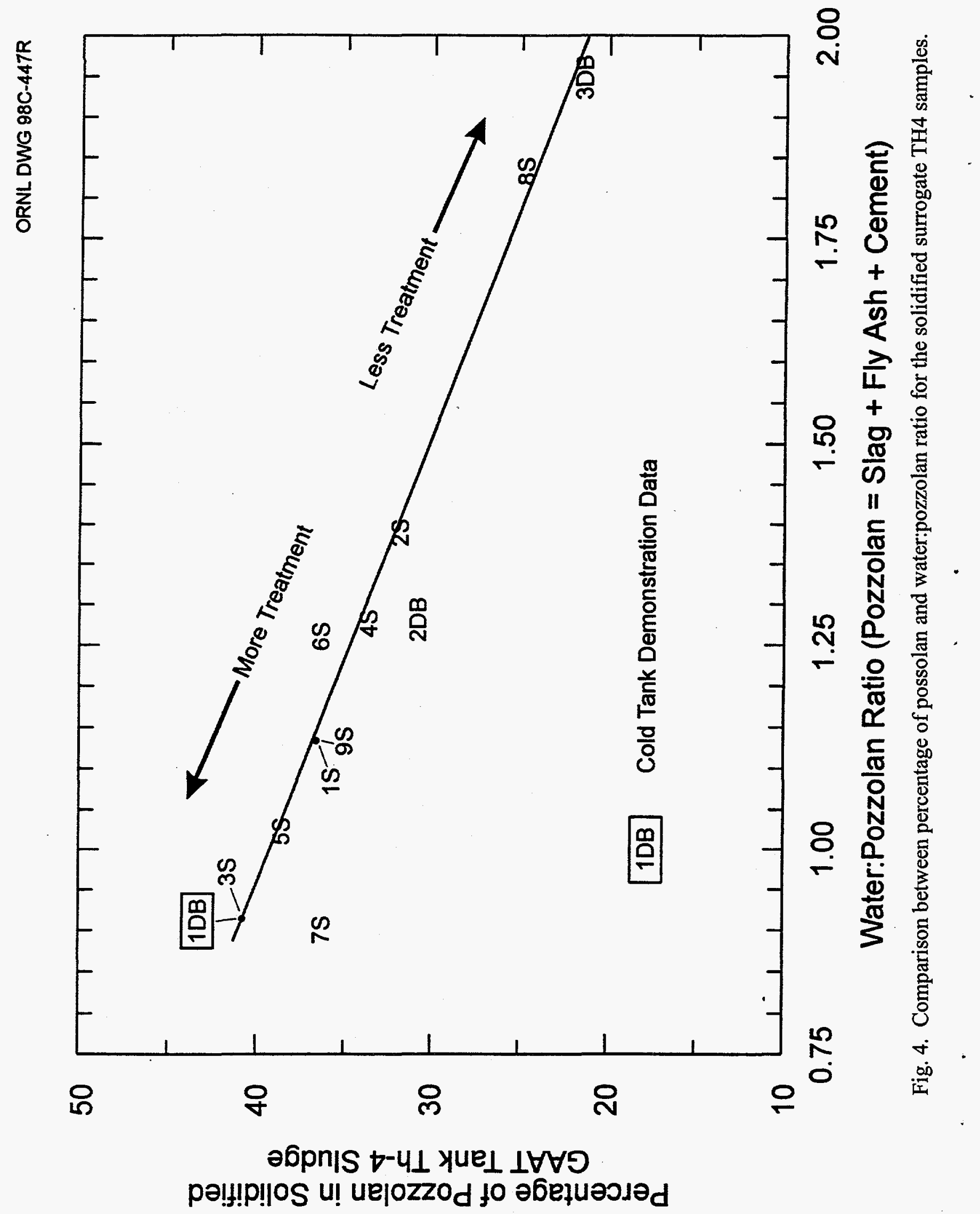




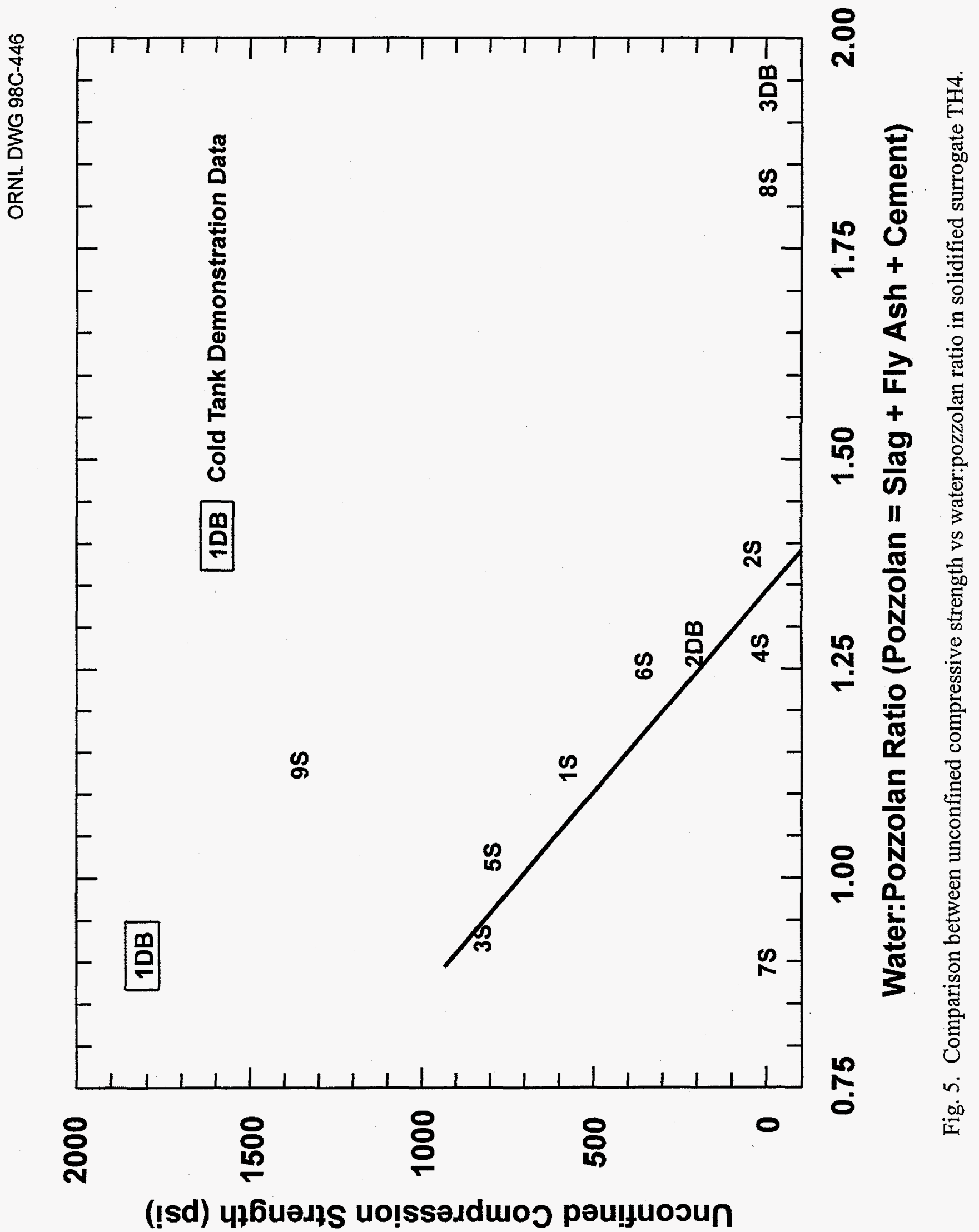




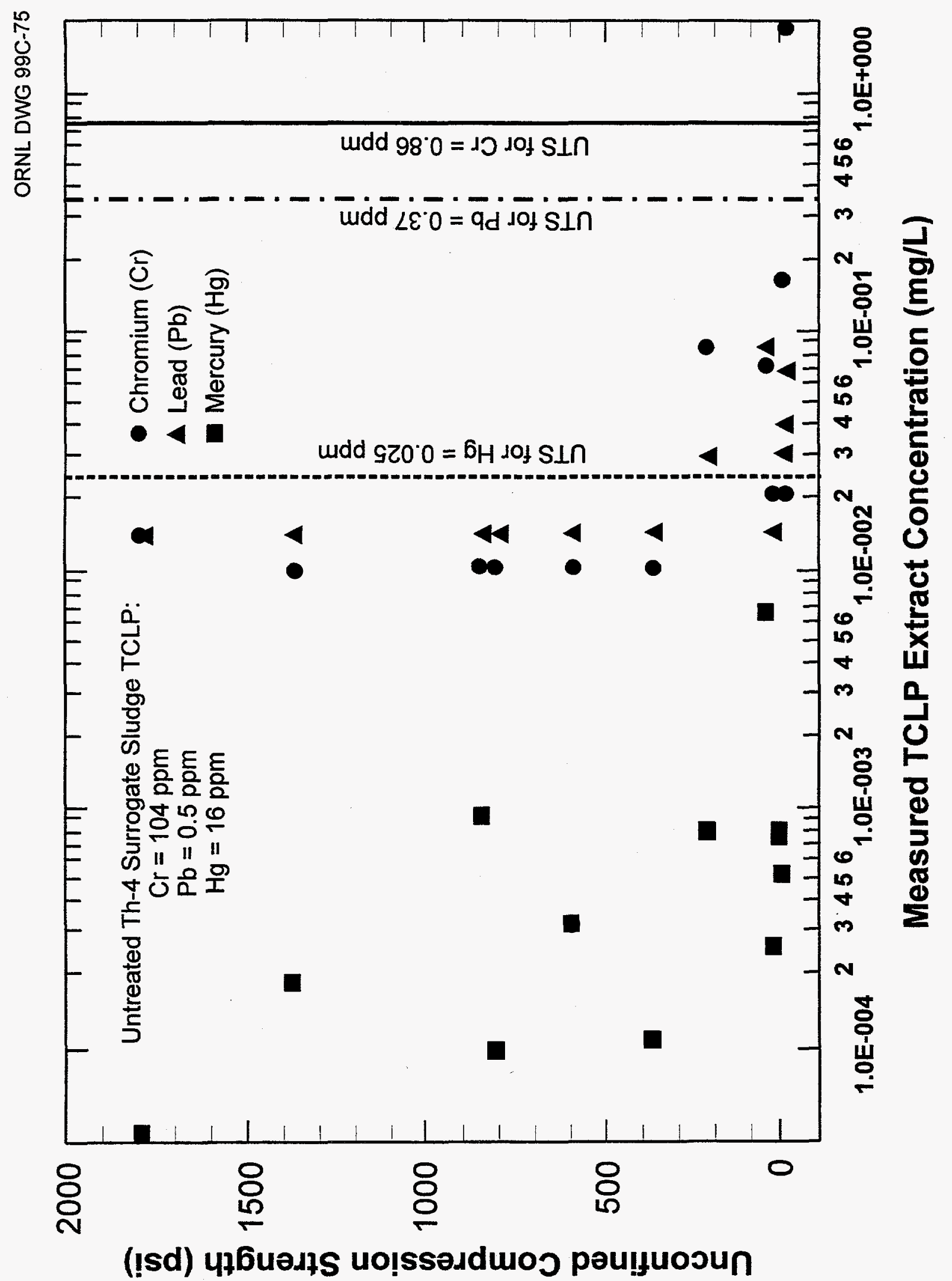

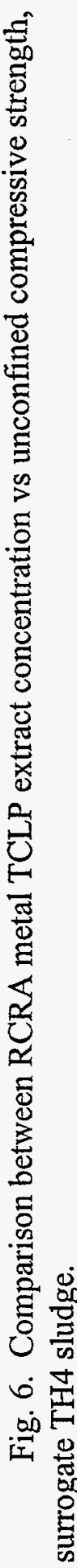




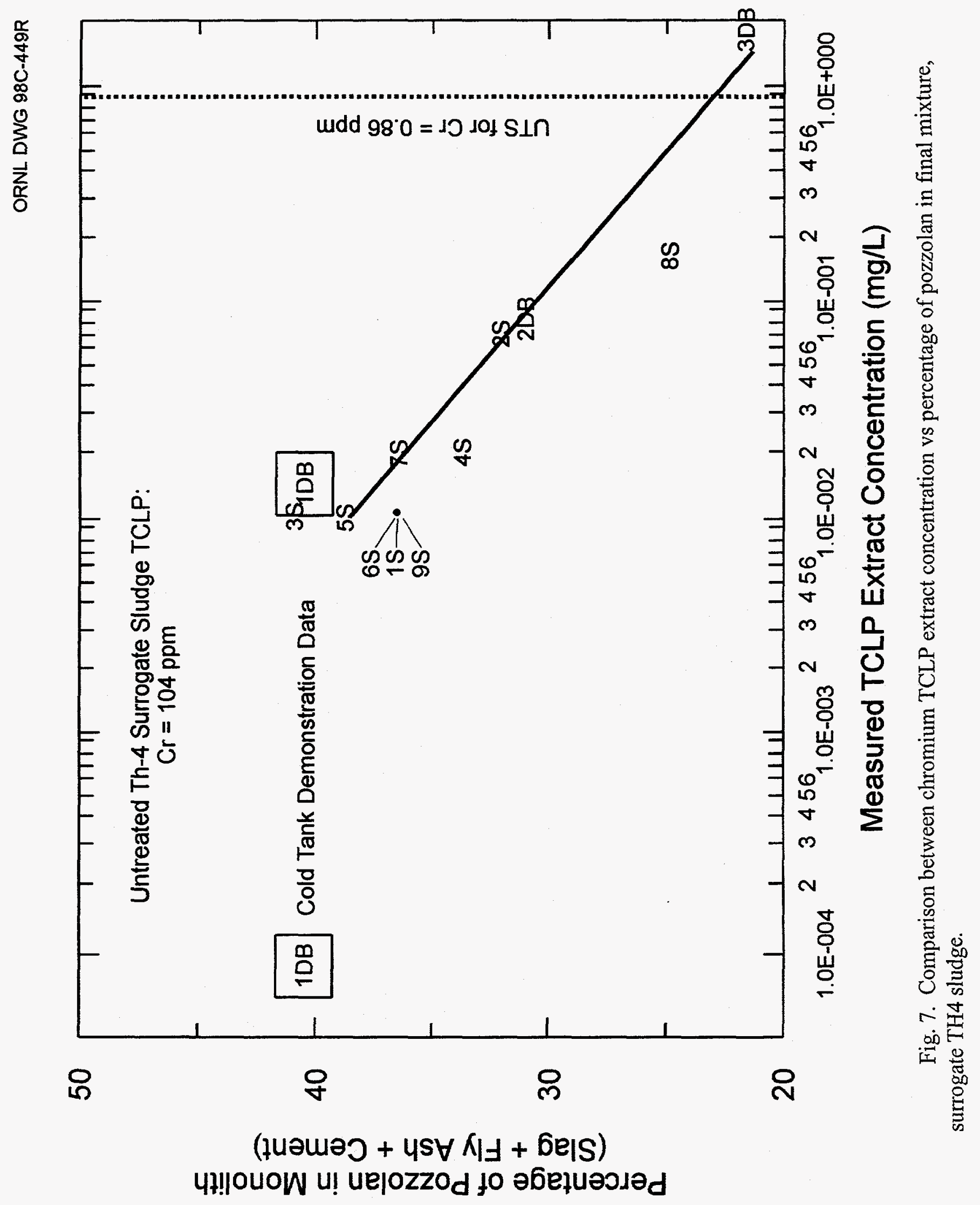




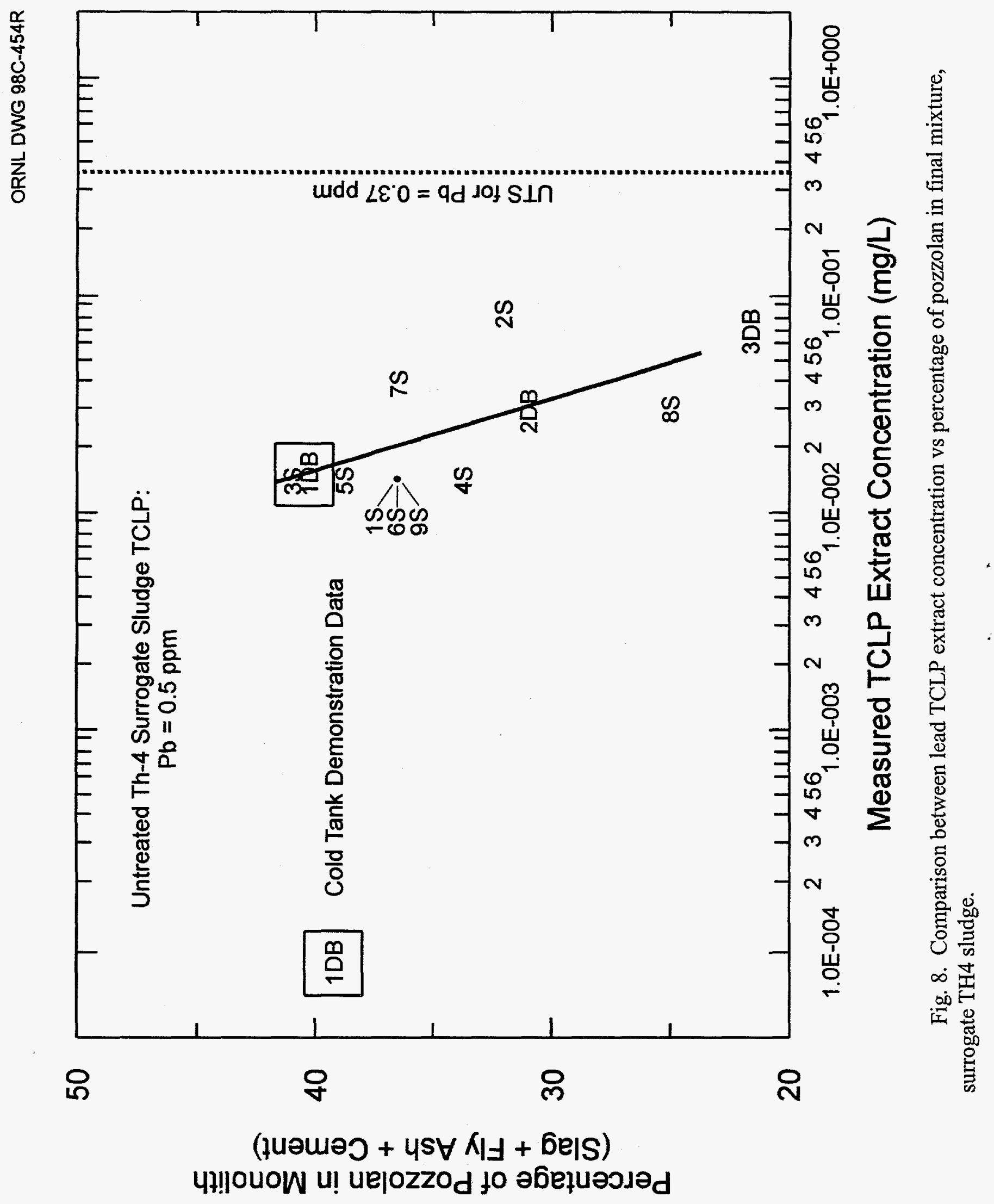




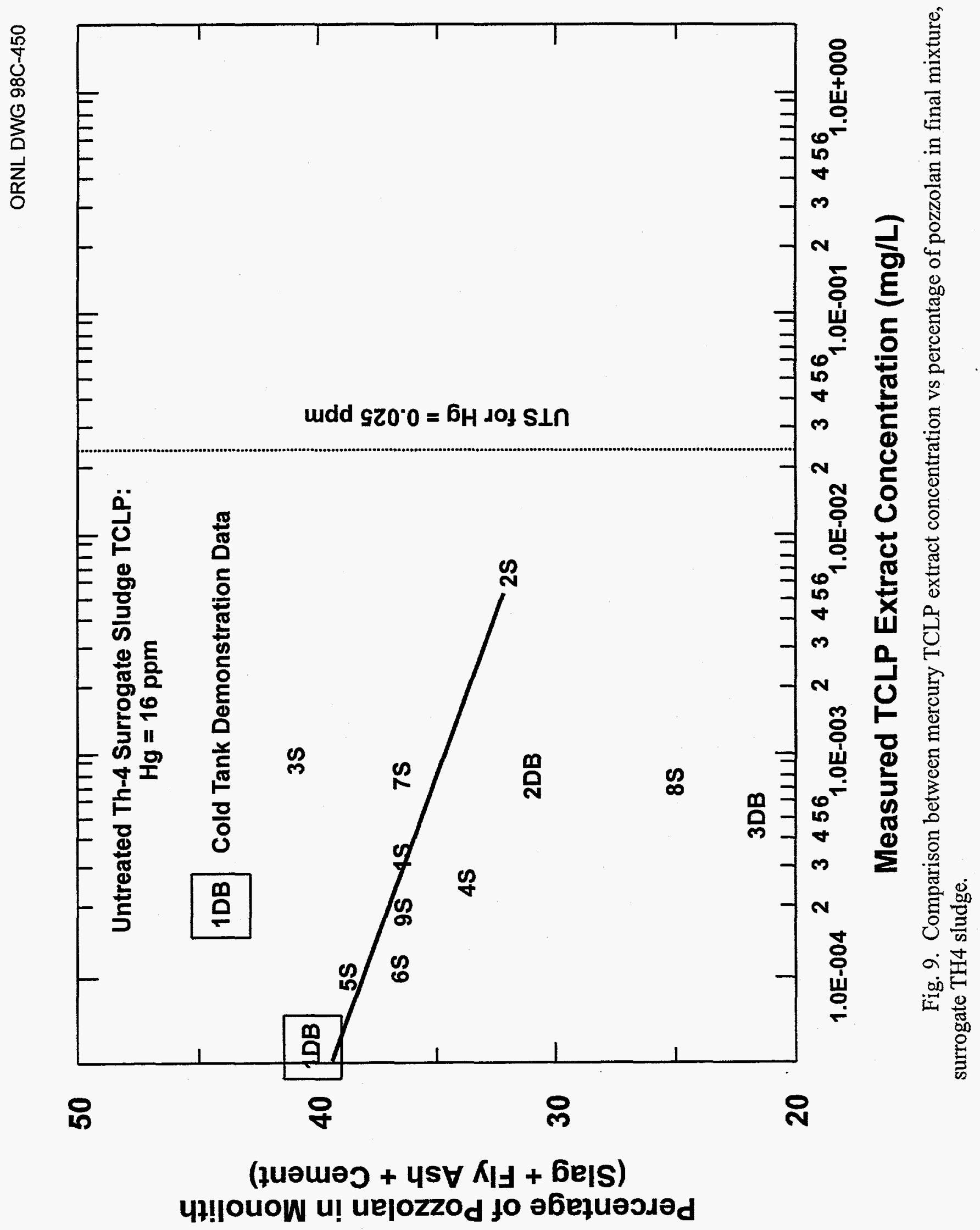




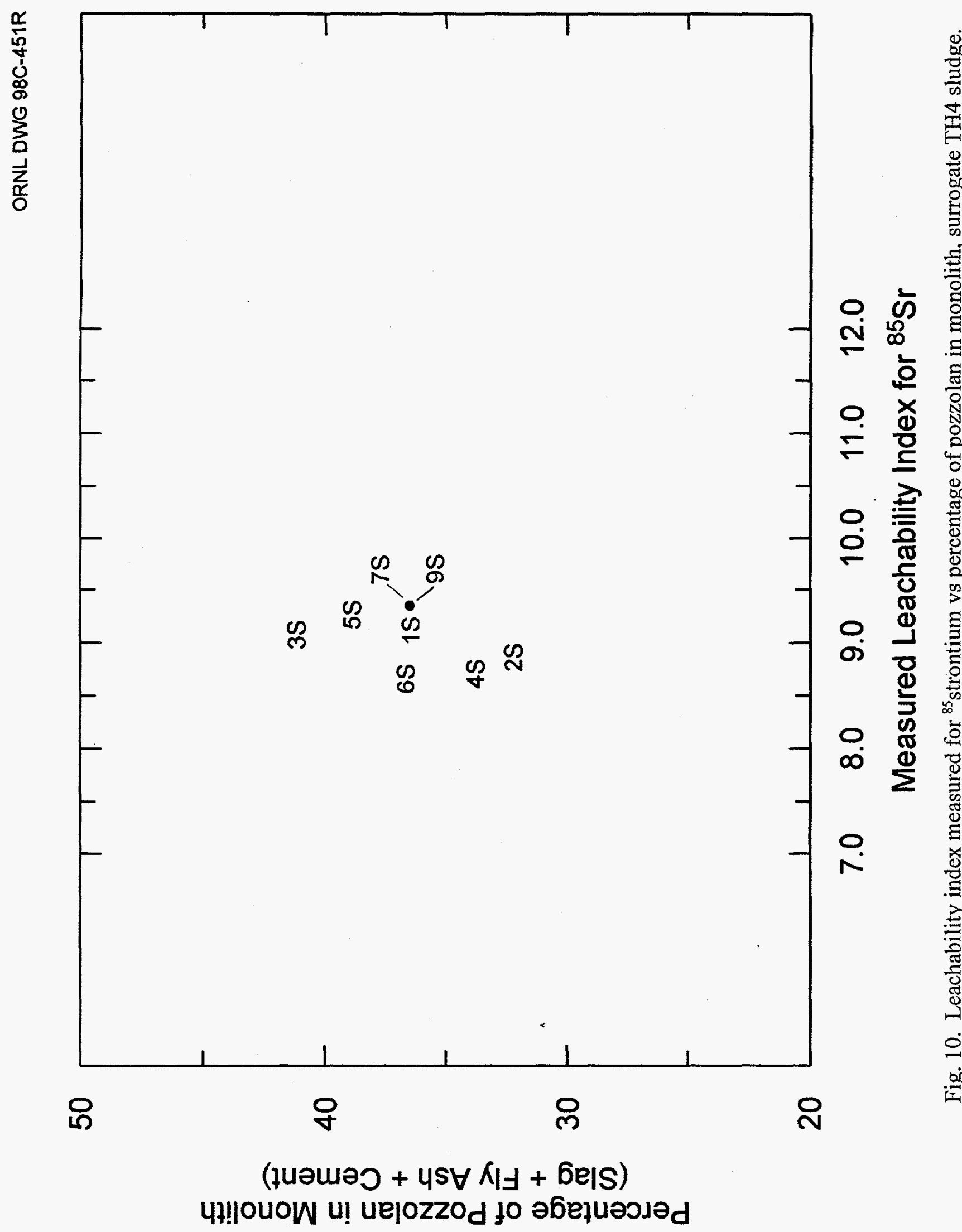




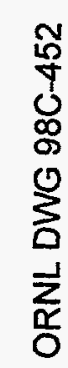

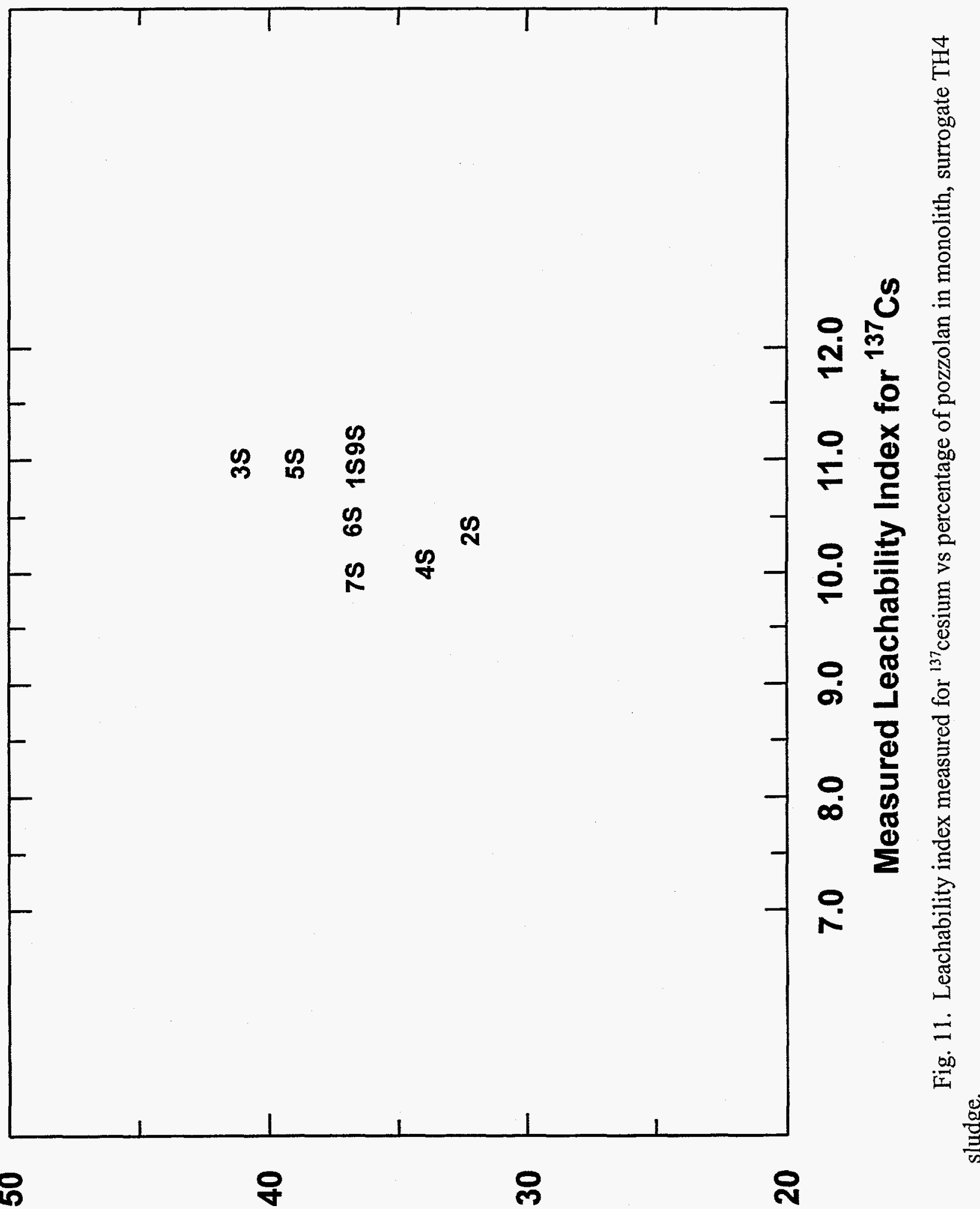



APPENDIX 

To: Roger Spence

From: Sophie Bobrowski foptu Boternte

Subject: XRD Analysis of Slag Samples (Req. 54379)

Date: September 23, 1998

Two slag samples, Holman (S-36) 9-1-98 and Halliburton 9-1-98, were analyzed by $\mathrm{x}$-ray diffraction analysis, energy dispersive $\mathrm{x}$-ray microanalysis (EDX), and by optical microscopy. Comparisons of the diffractograms and the EDX spectra (attached) do not show any significant difference between the two samples. The diffractograms show that both materials are largely amorphous. The EDX elemental analysis shows that both samples contain $\mathrm{Al}, \mathrm{Ca}, \mathrm{Cu}, \mathrm{Fe}, \mathrm{K}, \mathrm{Mg}, \mathrm{Mn}, \mathrm{S}, \mathrm{Si}, \mathrm{Ti}$, and $\mathrm{Zn}$ in roughly the same amounts and in similar proportions. Optical analysis does show a difference between the slags. The Halliburton slag optically appears to consist of smaller glass particles and bigger crystalline particles than the Holman slag.

The optical results suggest that particle size may be an important factor that is contributing to the different setting properties that you have observed in your work. You might want to consider having a particle size analysis done on your sample. This lab does have a scanning electron microscope and imaging software that could be used for the particle sizing work. X-ray dot mapping could also possibly be used to discern the crystalline particles from the glassy ones.

If you should have any questions do not hesitate to call me at 574-4877. Thank you . 


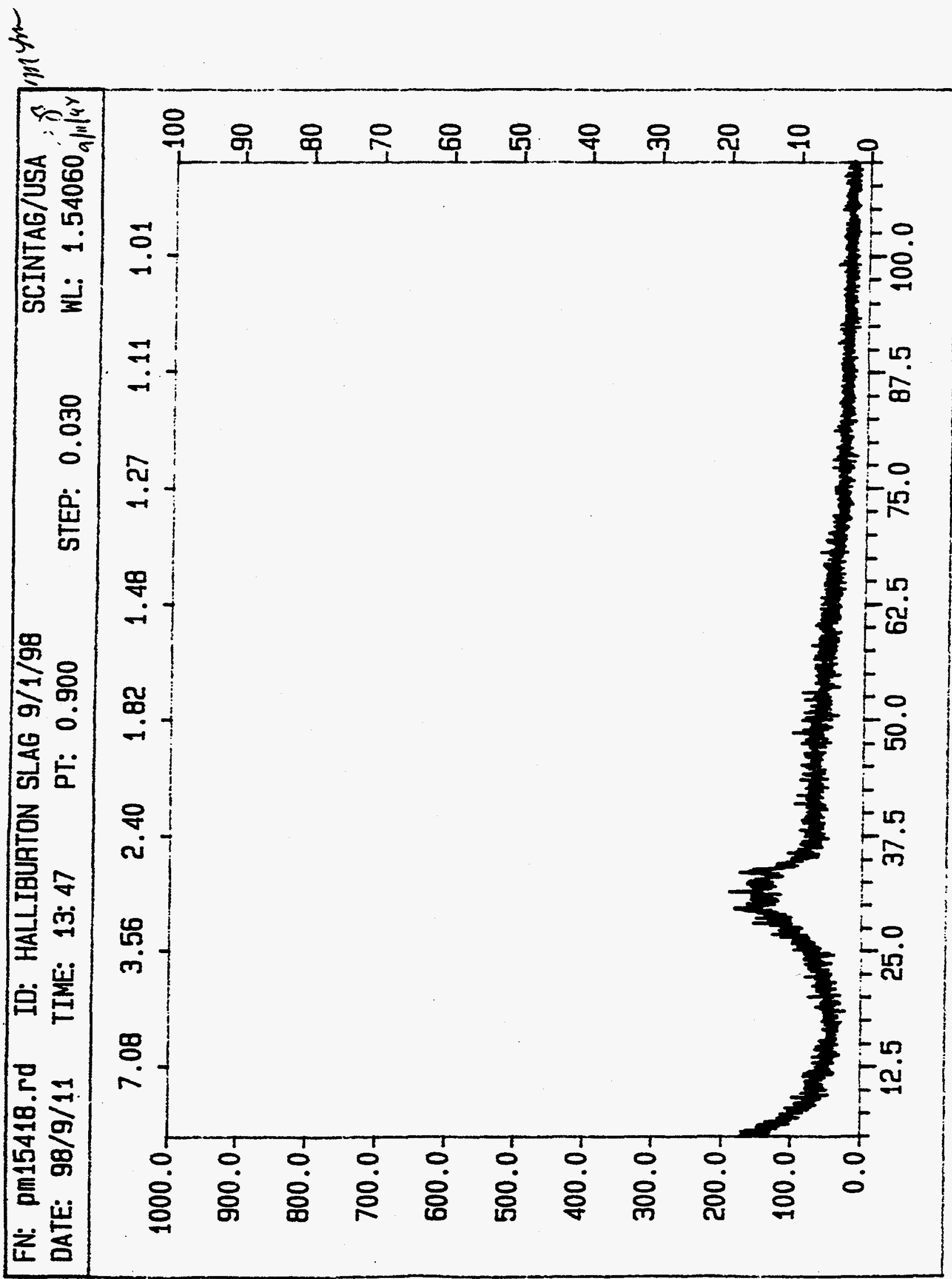




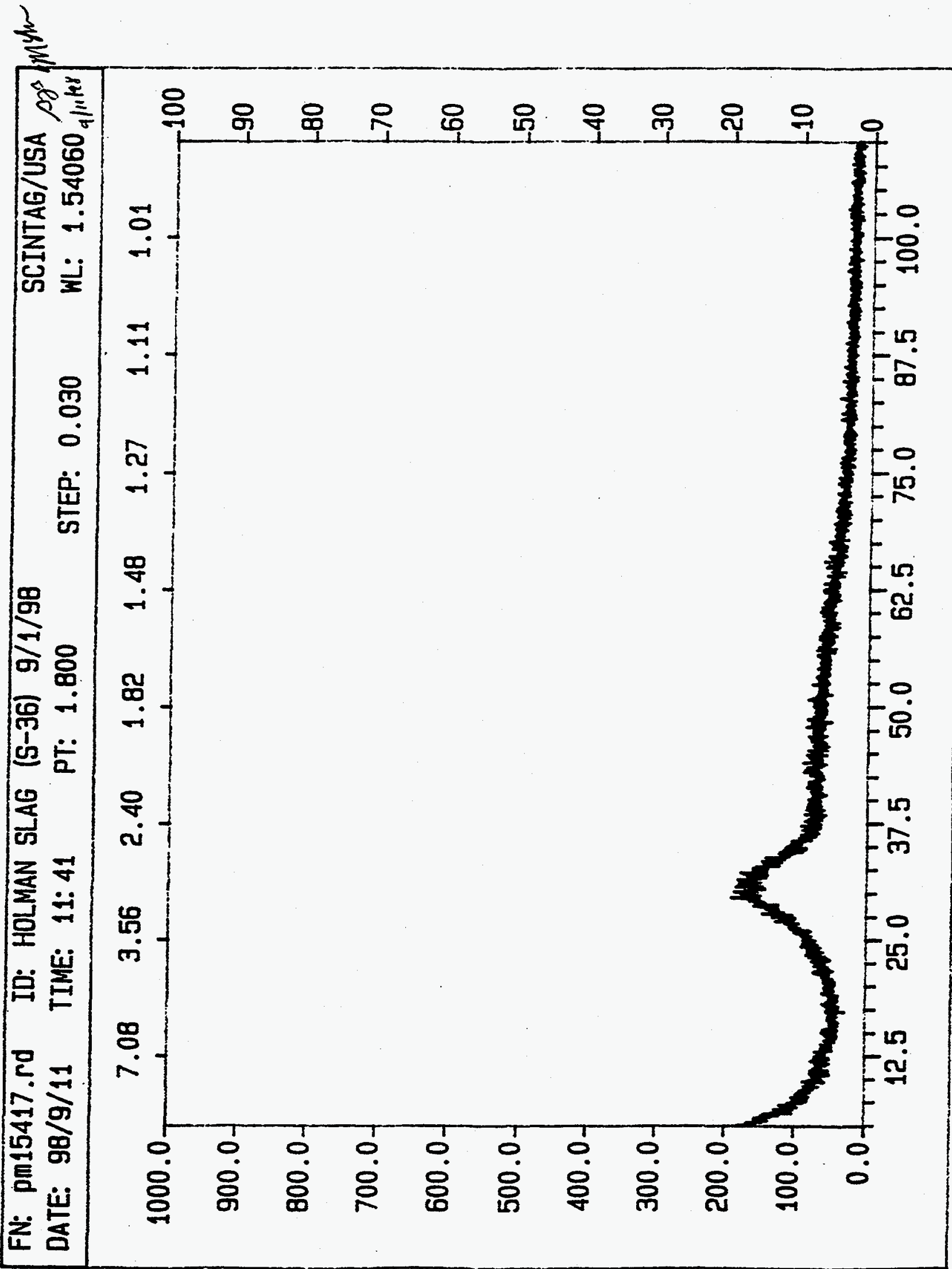




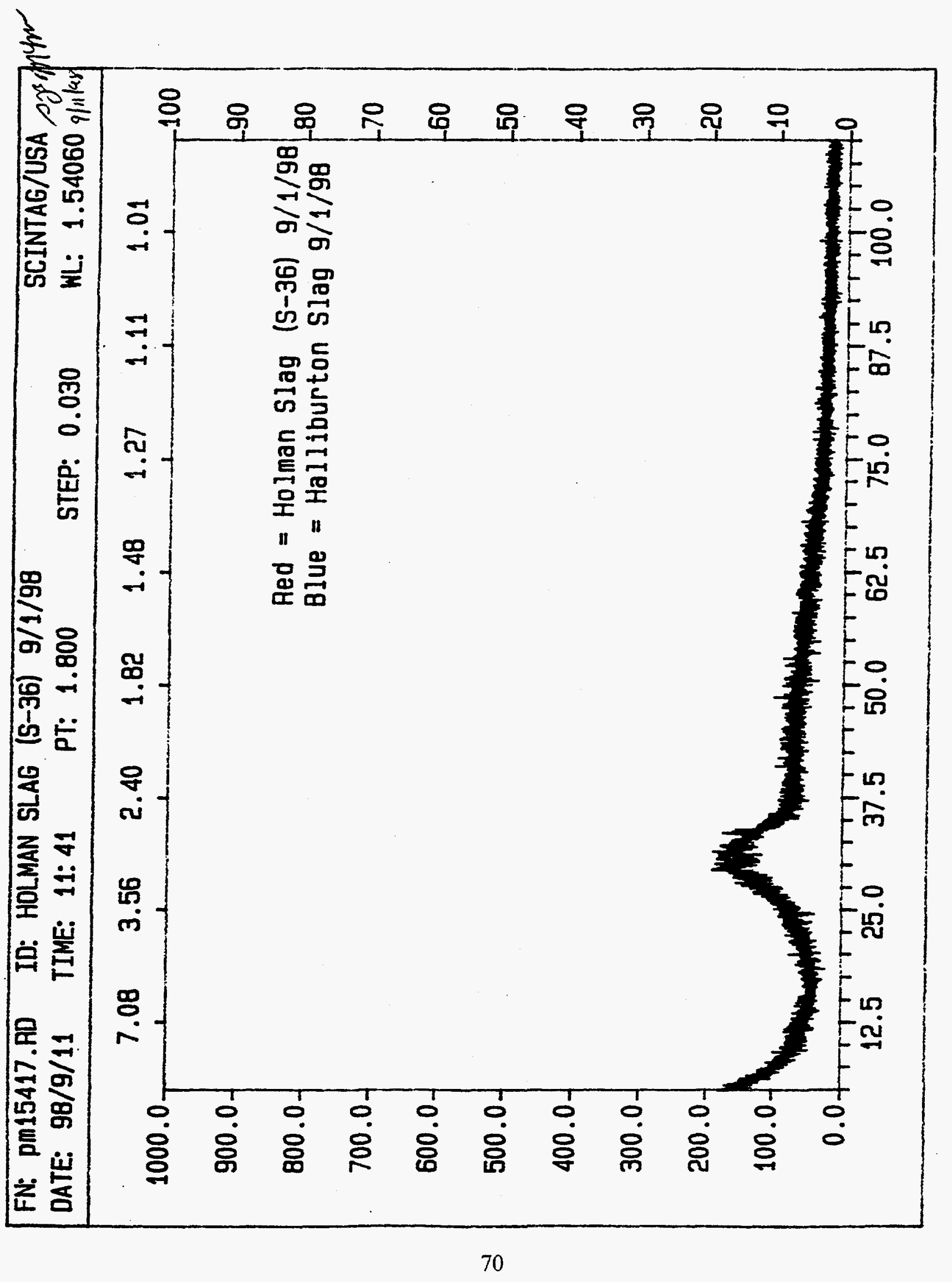


HNU X-RAY System 5000

Spectrum Plotting Program

Printplot V3.000

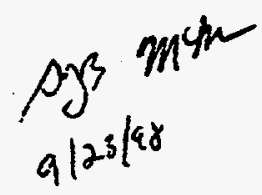

Sample ID: Holman Slag (S-36) (PM15417:R.Spence)

Energy Range: $0-20 \mathrm{keV} 10 \mathrm{eV} / \mathrm{ch}$

Preset: Live Time $100 \quad$ Seconds

Real Time: 128.37 Sec. Live Time: $100.00 \mathrm{Sec}$.

22\% Deadtime 3387 Counts/Second

Acquisition date: $23-\operatorname{Sep}-98$ Acquisition time: $17: 35=18$

\section{Cfs 8K}

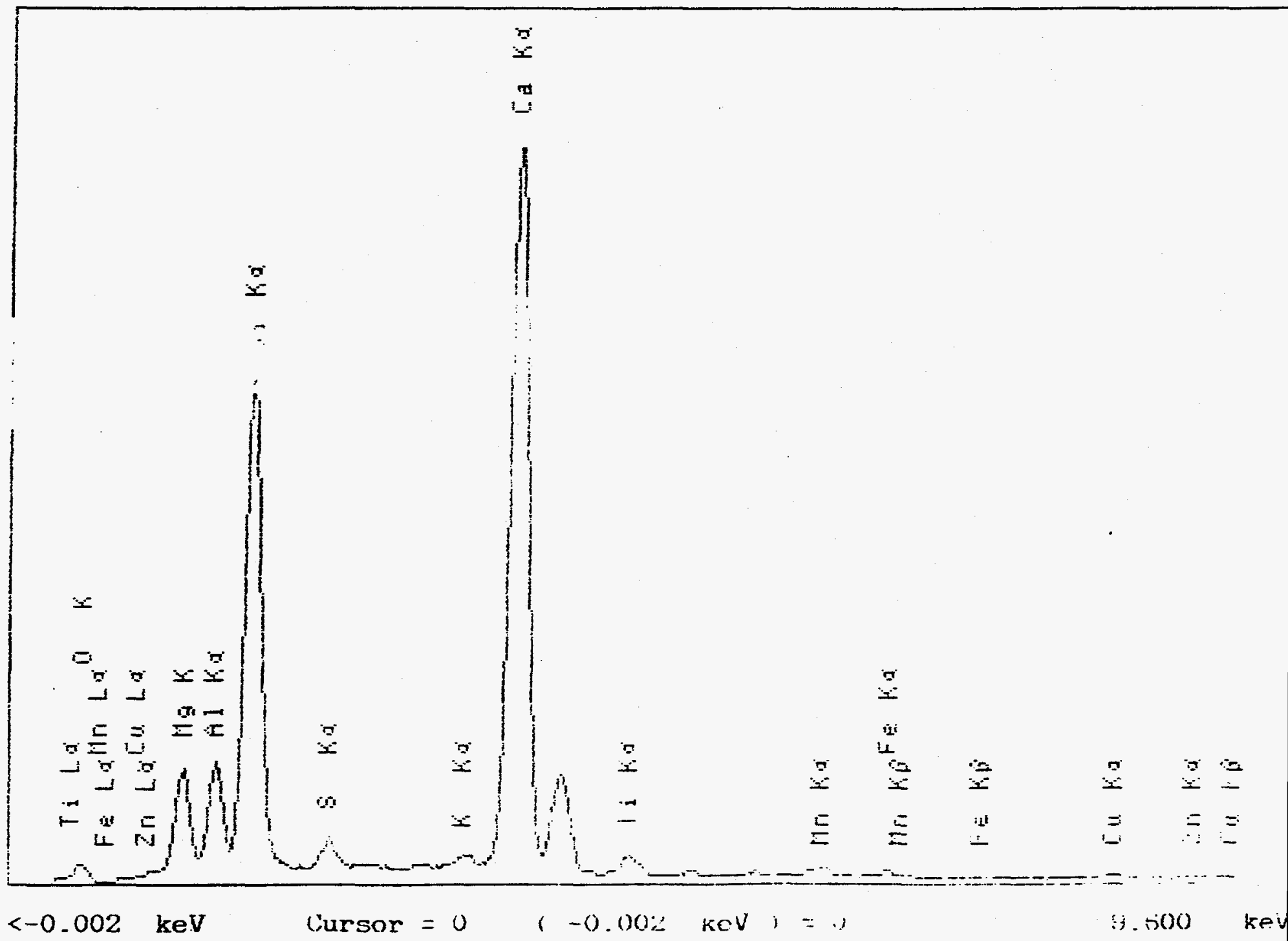


HNU X-RAY System 5000

Spectrum Plotting Program

Printplot V3.000

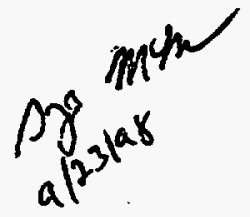

Sample ID: Halliburton Slag (PM15418:R.Spence)

Energy Range: $0-20 \mathrm{keV} 10 \mathrm{eV} / \mathrm{ch}$

Preset: Live Time 100

Seconds

Real Time: 125.33 Sec.

Live Time: 100.00 Sec.

22\% Deadtime 3225 Counts/Second

Acquisition date: 23-Sep-98 Acquisition time: 17:49:51

Cfs BK

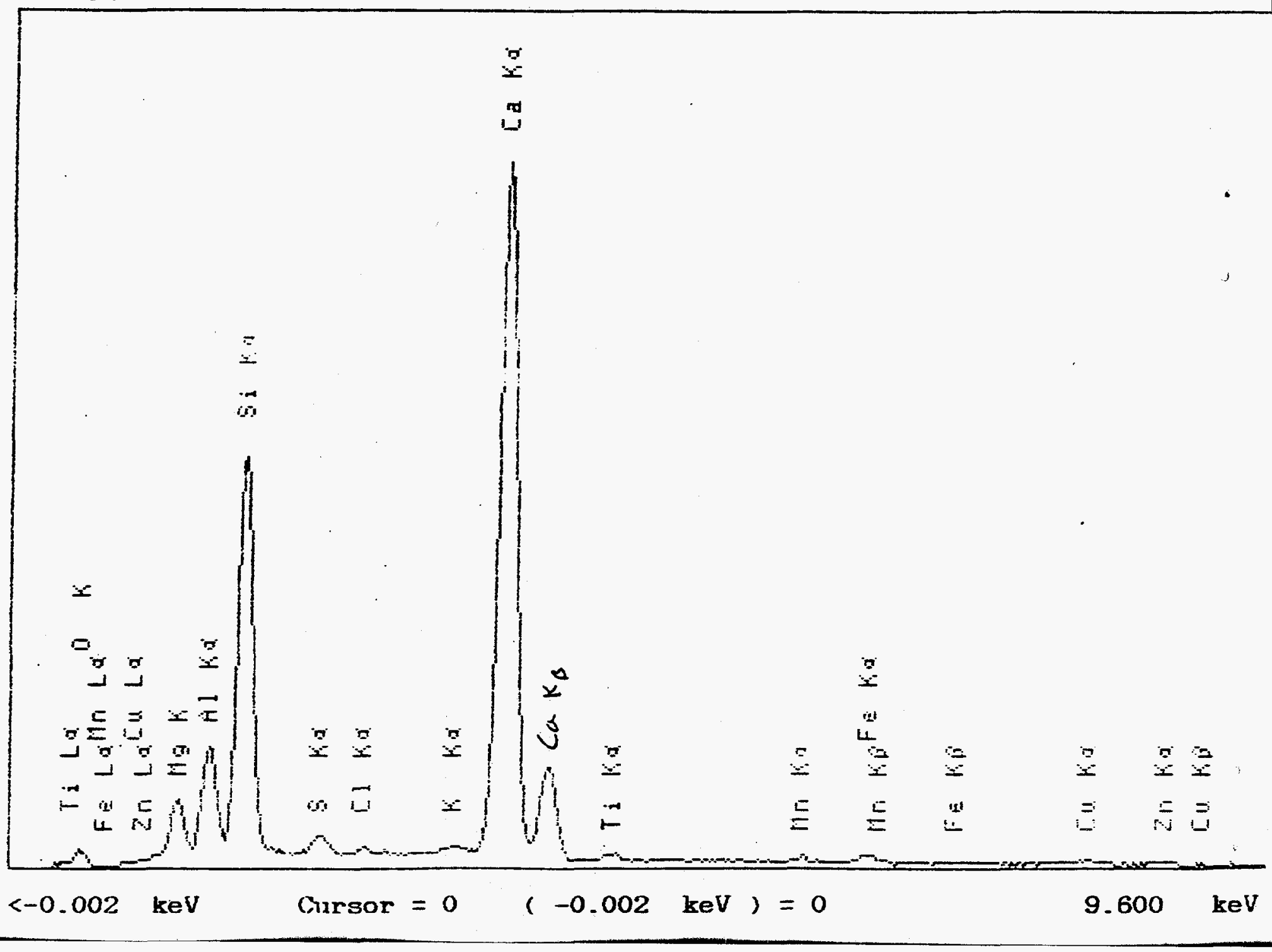

